March 2019. Forthcoming in Sociology.

\title{
THE RHETORIC OF RECESSIONS: HOW BRITISH NEWSPAPERS TALK ABOUT THE POOR WHEN UNEMPLOYMENT RISES, 1896-2000*
}

\author{
Daniel McArthur ${ }^{\dagger}$ and Aaron Reeves ${ }^{\ddagger}$
}

March 8, 2019

\begin{abstract}
:
Recessions appear to coincide with an increasingly stigmatising presentation of poverty in parts of the media. Previous research on the connection between high unemployment and media discourse has often relied on case studies of periods when stigmatising rhetoric about the poor was increasing. We build on earlier work on how economic context affects media representations of poverty by creating a unique dataset that measures how often stigmatising descriptions of the poor are used in five centrist and right-wing British newspapers between 1896 and 2000. Our results suggest stigmatising rhetoric about the poor increases when unemployment rises, except at the peak of very deep recessions (e.g. the 1930s and 1980s). This pattern is consistent with the idea that newspapers deploy deeply embedded Malthusian explanations for poverty when those ideas resonate with the economic context, and so this stigmatising rhetoric of recessions is likely to recur during future economic crises.
\end{abstract}

\section{INTRODUCTION}

The global financial crisis of 2008 seemed to coincide with a rise in stigmatising rhetoric about people in poverty and welfare recipients across a range of print and television media outlets (Harkins and Lugo-Ocando, 2016; Tyler, 2008, 2013). This language legitimised welfare retrenchment by 'othering' (Lister, 2015) people in poverty and representing them as part of an out-group who were lazy, immoral, and living fraudulently at the expense of hard-working taxpayers (Jensen, 2014). Anti-welfare narratives permeated public discourse over this period and

\footnotetext{
*Replication materials are available here: https://github.com/asreeves/rhetoric-recessions

${ }^{\dagger}$ London School of Economics and Political Science, d.mcarthur@lse.ac.uk

${ }^{\ddagger}$ London School of Economics and University of Oxford, aaron.reeves@spi . ox . ac.uk
} 
in some cases even had a demonstrable impact on attitudes toward welfare recipients (Reeves and de Vries, 2016).

This latest crisis is one recent example of how parts of the media stigmatise the poor during periods of rising unemployment. A number of studies have argued that media rhetoric about the poor responds to macroeconomic conditions, becoming more stigmatising when times are hard (Golding and Middleton, 1982; Macnicol, 1987). However, the existing quantitative evidence linking economic crises and newspaper rhetoric about the poor remains limited. Existing work relies on time-consuming hand-coding (Gilens, 1996; Misra et al., 2003), which limits the ability of researchers to examine long term trends in the language newspapers use to describe the poor. We know of no quantitative studies that investigate whether the prevalence of stigmatising language about the poor is affected by underlying economic conditions. ${ }^{1}$ Case studies have generated crucial insights into how the print media frame poverty during economic downturns and periods of high unemployment but they have done so by examining precisely those periods in which stigmatising rhetoric increased. This logic of case selection may inadvertently overlook periods when, for example, unemployment rises but there is no change in stigmatising rhetoric (Deacon, 1976).

We address this gap in research on the link between economic crises and newspaper rhetoric about poverty by drawing on a unique dataset measuring how often five right-wing and centrist British newspapers and periodicals use stigmatising language about people in poverty throughout the twentieth century (1896-2000). We find that stigmatising rhetoric about the poor becomes more common when unemployment increases, but this association weakens when unemployment rates are especially high (>10\%), such as during the 1930s and the 1980s.

Outside these exceptional periods, we conclude that British centrist and right-wing newspapers deploy deeply embedded Malthusian anxieties about the behaviour of the poor when unemployment is rising. In doing so they draw on a powerful set of ideas to explain an economic phenomenon that by itself might threaten the hegemony of individualistic interpretations of unemployment and poverty. Adopting an historical perspective reveals how deeply embedded ideas, such as Malthusian explanations for poverty, are deployed when they resonate with the structural context. Media stigmatisation of the poor following the global financial crisis was consistent with how our sample of newspapers responded to changing economic conditions across the twentieth century.

\section{RECYCLING MALTHUS: MEDIA RESPONSES TO HIGH UNEMPLOYMENT IN HIS- TORICAL CONTEXT}

While the media reaction to the global financial crisis in the UK intensified anti-welfare rhetoric (Jensen, 2014; Jensen and Tyler, 2015), such concerns about the numbers and morality of the poor and the unemployed are not new, and can be traced back over many centuries (Day, 2001;

\footnotetext{
${ }^{1}$ Rose and Baumgartner (2013) use a similar methodology to our own. However, their study of how poverty is framed in the US covers a substantially shorter time period (48 years vs 105 years in our study), and focuses on the consequences rather than the determinants of media rhetoric about the poor.
} 
Welshman, 2007). ${ }^{2}$ Thomas Malthus' Essay on the Principle of Population (2008), first published in 1798, has had an enormous influence on how poverty is understood in British society (Golding and Middleton, 1982; Harkins and Lugo-Ocando, 2016; Macnicol, 1998).

Malthus argued that providing welfare is counterproductive because it breaks the natural check that starvation places on the numbers of the poor. In his view, the poor would not work if they are not required to do so to survive, and so providing them with food would erode their work ethic. Furthermore, their inability to exercise sexual restraint means that their numbers would inexorably increase, leading to collective immiseration and eventual societal collapse. When people refuse to work, unemployment rises, and so rising unemployment becomes a symptom of the moral decay that will make societies unsustainable, unless action is taken to reduce welfare uptake and dis-incentivise welfare dependency. To this end Malthus argued that welfare receipt should be stigmatised: 'hard as it may appear in individual instances, dependent poverty ought to be held disgraceful' (Malthus, 2008: III.VI.5).

Malthusian ideas have had a profound influence on public and policy discourse for nearly 200 years, shaping the Poor Law debates of the 1830s (Malthus, 2008; Polanyi, 2002), the welfare reforms of the 1980s and 1990s (Somers and Block, 2005), and austerity policies following the Great Recession (Harkins and Lugo-Ocando, 2016; Jensen and Tyler, 2015).

Malthus's influence can be clearly seen in media responses to unemployment. Public debates about poverty during the 1890 s and early 1900 s - an economically turbulent period when unemployment fluctuated wildly - were dominated by concerns about the spread of a 'degenerate nature' among the worst off in society, the 'social residuum' or 'unemployables' (Welshman, 2007: 2, 21; see also Day, 2001). In 1894, only a year after the peak of a recession, Geoffrey Drage (Secretary to the Labour Commission) argued that unemployment was mostly attributable to 'faults of character - habits of intemperance, idleness, or dishonesty' (Drage, 1894: 142).

When the Great Depression hit, parts of the press blamed 'dole' abusers for the country's economic difficulties rather than speculators or financiers (Golding and Middleton, 1982 Deacon, 1976). In August 1931, The Daily Telegraph called on the government to 'not be moved by the threatening invective of those who... [cry] "Hands off our dole". The government cut unemployment benefit by $10 \%$.

Between 1973 and 1976, a moral panic about welfare fraud coincided with a doubling of unemployment rates from $1.9 \%$ to 3.9\%. On 15 July 1976, the Daily Express' front page read 'Get the Scroungers!' This war on benefits cheats was widespread enough that around $30 \%$ of all social policy-related news stories in 1976 were concerned with welfare abuse. Such stigmatising rhetoric punctured the thin 'veneer of an apparent "welfare consensus" that had existed since WWII (Golding and Middleton, 1982) and legitimised major cuts to public spending.

\footnotetext{
${ }^{2}$ Demonisation of the poor in Britain goes back at least as far as the fifteenth century (Golding and Middleton, 1982). We focus on debates from about 1880 onwards in this paper because our data begins in 1896.
} 


\section{IDEATIONAL EMBEDDEDNESS AND THE MEDIA}

These historical episodes make it clear that the print media has repeatedly played a crucial role in framing recessions in Malthusian terms, raising the question about why journalists recurrently deploy this language amidst rising unemployment. Part of the explanation seems to be that Malthusian ideas have been 'ideationally embedded' in the culture of Anglophone countries: they have become central features of the narratives and explanatory systems that social actors use to explain the world, often without realising their source (Somers and Block, 2005: 264). The success of Malthusian explanations of poverty is rooted in the capacity of this theory to make itself true by changing the features of the world that appear salient to people, including journalists (Bourdieu, 1998: 95). For example, living in a society where Malthusian explanations are central to how people understand poverty means people can now see the perverse effects of welfare almost everywhere they look. Despite the fact that there are vanishingly few people who actually refuse to work, the dominance of the Malthusian narrative makes it possible for people to believe that such behaviour is commonplace (Macdonald et al., 2014). By 'making themselves true', Malthusian ideas have become a form of common sense, accepted across society. So deeply embedded are these narratives in the Anglophone world that even those in poverty often deploy such images and tropes (Shildrick and MacDonald, 2013).

From this perspective, journalists are not the sole creators of stigmatising rhetoric, they are simply one set of actors who are 'engaged in the production and maintenance of meaning' and who are part of a discourse that renders some kinds of occurrences more meaningful than others (Benford and Snow, 2000). Like politicians and the general public, journalists deploy Malthusian ideas because they are engaged in a process of reproducing and recirculating widely accepted ways of understanding the social world (Couldry and Hepp, 2016). Journalists also possess a high degree of power to shape public opinion and government policy through the way they deploy these discourses in framing the issues of the day. ${ }^{3}$ Therefore, it is worth considering how journalists' relationship to their readers, and the economic context, may make them more or less likely to draw on Malthusian explanations for poverty.

\section{WHY NEWSPAPERS USE MALTHUSIAN IDEAS IN RECESSIONS}

Whatever their goal or agenda, journalists need to effectively communicate with their readers. To do so, journalists draw on evocative and recognisable tropes, metaphors, or images. As described above, Malthusian ideas provide a rich and compelling set of narratives journalists can use to frame their explanations of social phenomena (Gamson and Lasch, 1983; McKendrick et al., 2008). ${ }^{4}$ Malthusian ideas will not be ever-present in media discourse, rather, journalists are more likely to deploy them when they resonate most strongly with readers' experiences and the broader context (Benford and Snow, 2000; Gamson, 1992). Rising unemployment is a set of circumstances that Malthusian ideas explain well by providing a simple theory whereby an

\footnotetext{
${ }^{3}$ For detail about the processes by which individuals draw on media framings to make their minds up about social and political issues see Gamson (1992).

${ }^{4}$ This account abstracts from a number of important aspects of media production, such as the role of newspaper owners or editors. This is not because we believe these aspects are unimportant but rather that they are not central to argument we are making in this paper. We return to this issue in the discussion.
} 
increasing population in poverty is a natural result of the immorality of the poor (Somers and Block, 2005). As a result, when unemployment rates go up, stigmatising rhetoric in the print media should increase because this is when Malthusian ideas are at their most relevant as a way of making sense of changing economic conditions. By contrast, when unemployment declines, and the Malthusian explanation of poverty becomes less relevant to the circumstances, stigmatising rhetoric should decline as well.

This 'Malthusian' theory has never been tested quantitatively. Thus it is also possible that when unemployment is rising it becomes harder to maintain that 'faults of character' (Drage, 1894) are the cause of joblessness, and as a result structural explanations of poverty may resonate more strongly with economic context and newspaper readers' experiences (van Oorschot, 2006, Benford and Snow). From this perspective, when unemployment rates go up stigmatising rhetoric in the media will decline, reflecting the increased resonance of structural explanations of poverty.

The central question of this paper is thus whether newspapers use stigmatising rhetoric about people in poverty more frequently when unemployment rates go up, or when they decline. Our analysis addresses this question by drawing on a novel data set covering the entire twentieth century, allowing us to connect macroeconomic conditions with how newspapers talk about people living in poverty.

\section{DATA AND METHOD}

\section{STIGMATISING RHETORIC IN NEWSPAPERS}

We construct a unique data set measuring the frequency of stigmatising language about people in poverty over the twentieth century. The Gale NewsVault database contains archives of five British newspapers from their inception to the present day: The Mail (daily and Sunday editions), The Telegraph (daily and Sunday editions), The Times (daily and Sunday editions), Financial Times, and the Economist. While there is some diversity among these papers in their political alignment and readership demographics, they are all are predominantly centrist or right-wing in orientation and are read by a largely middle-class audience (see Web Appendix 1 for further information). Unfortunately, the Gale NewsVault database does not contain any left-wing newspapers. As a result, we are unable to say whether left-wing newspapers are more likely to use stigmatising language when unemployment increases.

We restrict our sample to 1896-2000, when all five newspapers are available. To calculate the frequency of stigmatising language about people living in poverty we utilise Gale NewsVault's search function. This returns the frequency of articles containing specific terms by year. ${ }^{5}$

\footnotetext{
${ }^{5}$ For evidence that our strategy of counting word usage in newspapers is a valid measure of newspaper coverage of current events see Lansdall-Welfare and colleagues' (2017) analysis of a database of British newspapers from 1800-1950.
} 


\section{WORD CHOICE}

Stigmatising language about the poor frames people in poverty as members of an outgroup and associates poverty with negative stereotypes asserting immoral behaviour. The specific language used to describe the poor has changed substantially over time; words used frequently in one period, such as 'unemployables' or the 'residuum' in the late 19th century, later drop out of common usage. Political entrepreneurs create new terms, such as the 'underclass' in the 1980s, to express a set of ideas that remains fairly static (Gamson and Lasch, 1983; Welshman, 2007). We select words following earlier research on how poverty is presented in the media (Day, 2001; Golding and Middleton, 1982; Tyler, 2013; Welshman, 2007), choosing a large number of words (28) on the assumption that historical idiosyncrasies in usage should average out. Our set of words includes terms which are used to describe people in poverty in a stigmatising or demeaning manner such as 'scrounger', 'skiver', or 'underclass' (Golding and Middleton, 1982). We also use terms that denote negative attributes that are commonly asserted to be associated with poverty such as 'lazy', 'feckless', or 'unemployable' (Welshman, 2007). When such terms are used they invoke negative stereotypes linking poverty with deviant and immoral behaviour, thus presenting poverty as shameful and othering the poor (Lister, 2015).

Our focus is on measuring the prevalence of stigmatising and othering rhetoric about the poor. We are not trying to measure the net 'mood' (balance of positive vs. negative coverage) of print media discourse about the poor (Rose and Baumgartner, 2013) because apparently positive words about poverty can be used with a stigmatising intent (consider the negative connotations of the word 'benefits' in contemporary political discourse), and the framing of articles can provoke stigmatising reactions in their readers even if the words they use are generally neutral (see Gilens, 1996 for evidence of how ostensibly neutral images change perceptions of welfare recipients).

We use the frequency (the absolute number of uses) of each word rather than a measure of popularity (the proportion of articles published in a year in which a given word appears), in both descriptive statistics and the regression models. This is because the total number of articles fluctuates substantially from year to year (including a drop at the start of WWII because of paper rationing) and so artificially shifts the relative popularity far more than the absolute frequency.

Table 1 provides descriptive statistics for our set of words. We include sparklines to show differences in how often these words are used over the period. Some words are used fairly consistently, such as 'tramp'. Others are popular only in the early 20th century, such as 'deserving poor', while others gain in popularity such as 'underclass', which was unused prior to the late 20th century. 
Table 1: Descriptive statistics for words measuring stigmatising rhetoric about the poor.

\begin{tabular}{|c|c|c|c|c|}
\hline Word & Average & Min & Max & Sparkline \\
\hline Peasant* & 948.30 & 467 & 2413 & \\
\hline Tramp* & 659.21 & 195 & 1216 & \\
\hline Beggar* & 332.31 & 46 & 1313 & \\
\hline Peon* & 305.90 & 46 & 587 & \\
\hline Pauper* & 175.58 & 10 & 844 & \\
\hline Dependency & 103.70 & 14 & 511 & \\
\hline Idler* & 85.61 & 22 & 202 & \\
\hline Lower class & 72.03 & 8 & 181 & \\
\hline Delinquent & 62.16 & 7 & 272 & \\
\hline Loafer* & 56.02 & 4 & 201 & \\
\hline Delinquency & 55.58 & 2 & 242 & \\
\hline Indigent & 50.02 & 2 & 241 & \\
\hline Vagrant & 40.94 & 4 & 138 & \\
\hline Feckless & 39.27 & 0 & 216 & \\
\hline Indolent & 30.60 & 5 & 85 & \\
\hline Unemployable & 24.62 & 0 & 80 & \\
\hline Vagrancy & 23.47 & 0 & 93 & \\
\hline Underclass & 22.19 & 0 & 225 & \\
\hline Deserving poor & 22.00 & 0 & 153 & \\
\hline Shirker* & 19.19 & 1 & 230 & \\
\hline Scrounger* & 16.80 & 0 & 130 & \\
\hline Residuum & 10.72 & 0 & 52 & \\
\hline Skiver* & 9.71 & 0 & 67 & \\
\hline Dependent on benefits & 7.86 & 0 & 45 & \\
\hline Criminal class & 7.30 & 0 & 19 & \\
\hline Workshy & 6.64 & 0 & 39 & \\
\hline Dangerous class & 5.20 & 0 & 15 & \\
\hline Riff raff & 1.66 & 0 & 20 & \\
\hline
\end{tabular}

Notes: Data from Gale Newsvault. Words ordered by descending average frequency. Sparklines are intended to give a sense of relative frequency of word across time (1896-2000) and should be read with respect to minimum and maximum for each word. 
Figure 1: Unemployment rates and stigmatising rhetoric about the poor in Britain, 1896-2000

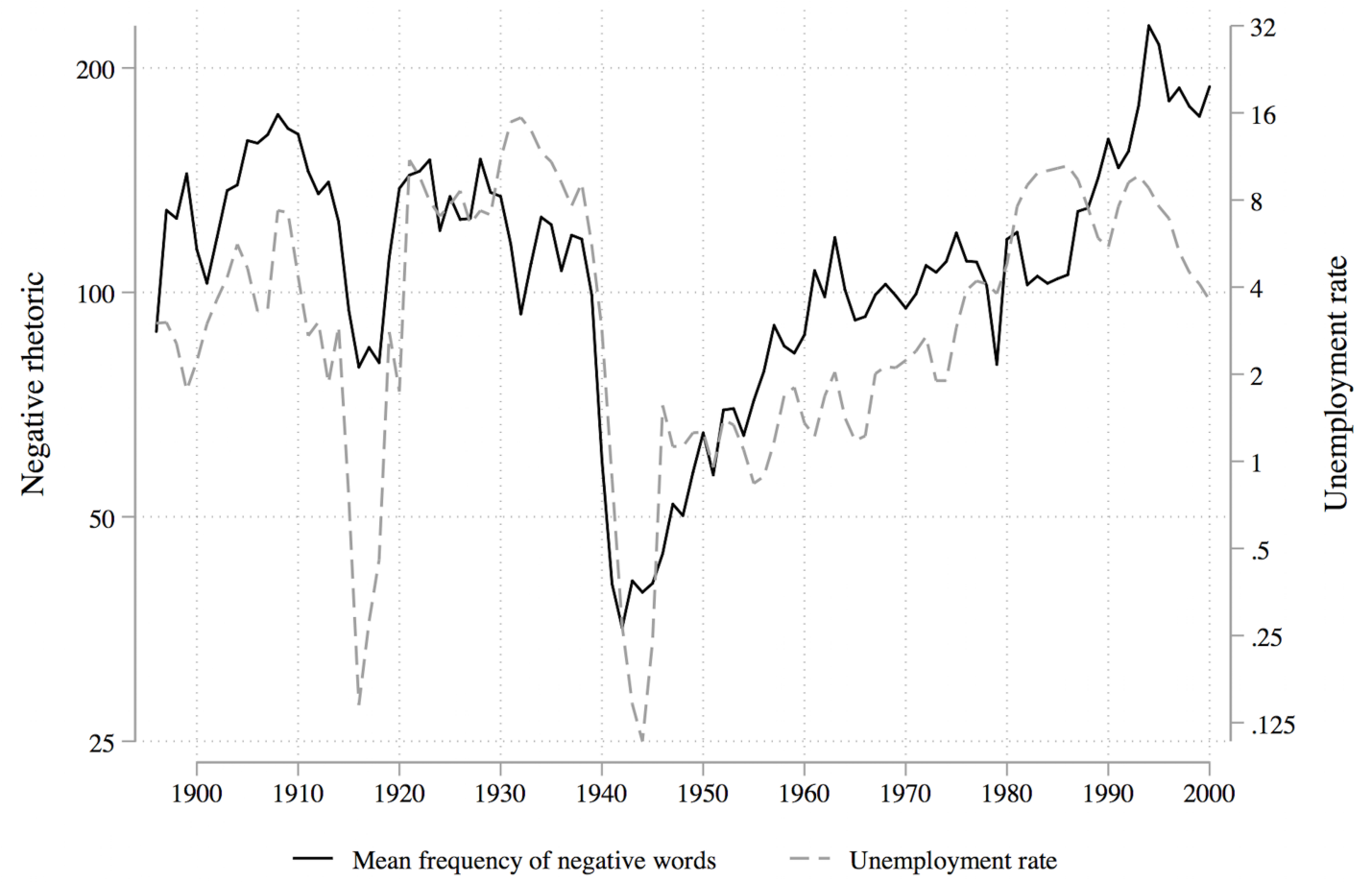

Notes: Both vertical axes are on a logarithmic scale.

In figure 1 we plot the average frequency of stigmatising rhetoric against unemployment rates across the twentieth century, taken from the Bank of England's 'Three Centuries of Macroeconomic Data' series (Thomas and Dimsdale, 2016). Across much of the 20th century these two lines seem to move together, suggesting that as unemployment rises so does stigmatising rhetoric $(r=0.705)$, providing some evidence in support of the 'Malthusian' hypothesis.

\section{NEWSPAPER RHETORIC AND UNEMPLOYMENT OVER THE TWEN- TIETH CENTURY}

Unemployment rates are a major driver of hardship for which measures are available covering the entire twentieth century (unlike measures of poverty, which are not regularly available until the mid 1960s). Furthermore, the morality and behaviour of the unemployed is central to how poverty has historically been discussed in the British print media, as the cases studies cited above indicate. Therefore, we focus on the relationship between unemployment rates and stigmatising rhetoric to understand how newspaper rhetoric about the poor depends on levels of poverty and hardship.

Looking more closely there are periods when this relationship does not hold. For example, 
at the beginning of the 1930s there is a sharp rise in unemployment that coincides with a reduction in the amount of stigmatising rhetoric. Then as unemployment rates gradually fall through the middle of the 1930s stigmatising rhetoric rises again. Similarly, during the 1980s we see this relationship become less clear. As unemployment rates rose between 1979 and 1980, there was a sharp increase in stigmatising rhetoric, but as unemployment continued to increase throughout the middle of the 1980s, stigmatising rhetoric seemed to decline, before rising steadily as unemployment fell.

Box 1: Statistical analysis

Our main model is a first difference model:

$$
\Delta \text { Rhetoric }_{t}=\alpha+\beta_{1} \Delta \text { Unemployment }_{t}+\beta_{2} \Delta \text { Articles }_{t}+\epsilon_{t}
$$

Where $t$ is year and $\Delta$ represents annual change. $\Delta$ Rhetoric is the annual change in the logged average number of stigmatising words used by our newspapers in each year, $\Delta U$ nemployment is the change in the logged unemployment rate, $\Delta$ Articles is the change in the logged number of articles published by these newspapers. $\alpha$ is our constant and $\epsilon$ is the error term. $\beta_{1}$ is the coefficient of interest and estimates the association between rising unemployment and changes in the amount of stigmatising rhetoric. Models 2 to 4 in table 2 add covariates to this basic specification (see Web Appendix 2 for descriptive statistics). $\Delta$ Rhetoric, $\Delta$ Articles, and $\Delta U$ nemployment, are all logged because they have highly non-normal distributions.

We also test for non-linearity in the relationship between changes in unemployment and changes in stigmatising rhetoric by including an interaction term between the level of unemployment and changes in the unemployment rate,

$$
\begin{aligned}
\Delta \text { Rhetoric }_{t}= & \alpha+\beta_{1} \Delta \text { Unemployment }_{t}+\beta_{2} \text { Unemployment }_{t} \\
& +\beta_{3} \Delta \text { Unemployment } \times \text { Unemployment }_{t} \\
& +\beta_{4} \Delta \text { Articles }_{t}+\epsilon_{t}
\end{aligned}
$$

All models account for autocorrelation using Newey-West standard errors with a second-order lag. We justify this lag-length in web appendix 3.

\section{ARE CHANGES IN UNEMPLOYMENT ASSOCIATED WITH CHANGES IN STIGMA- TISING RHETORIC?}

We further investigate the association between unemployment rates and stigmatising rhetoric using regression models (full details in Box 1). As our theory suggests, stigmatising rhetoric should respond to changes in unemployment because journalists and editors are probably more responsive to short-term changes in the economy (eg. $2 \%$ rise in unemployment) than longterm structural conditions (eg. low unemployment over the last 10 years). We estimate whether annual changes in unemployment are associated with annual changes in stigmatising rhetoric. This 'first difference' approach reduces the risk of identifying a spurious relationship, espe- 
cially if long-run trends in our key variables are correlated with other macroeconomic or political variables. We therefore model the response of the print media to changes in economic conditions rather than the underlying levels, taking into account the total number of articles published in any given year.

Table 2: Association between unemployment rate and stigmatising rhetoric adjusting for covariates, $1896-2000$

\begin{tabular}{|c|c|c|c|c|}
\hline & \multicolumn{4}{|c|}{$\begin{array}{c}\text { Annual change in the average frequency of } \\
\text { stigmatising words }\end{array}$} \\
\hline & (1) & (2) & (3) & (4) \\
\hline Increase in the unemployment & $0.058^{* *}$ & $0.042^{*}$ & $0.044^{* *}$ & $0.033^{*}$ \\
\hline rate $(\log )$ & $(0.019)$ & $(0.017)$ & $(0.016)$ & $(0.016)$ \\
\hline Increase in the number of & $0.77^{* * *}$ & $0.68^{* * *}$ & $0.82^{* * *}$ & $0.77^{* * *}$ \\
\hline published articles (log) & $(0.13)$ & $(0.14)$ & $(0.11)$ & $(0.13)$ \\
\hline \multirow[t]{2}{*}{ Defence spending (\%GDP) } & \multicolumn{3}{|c|}{$-0.0047^{* * *}$} & -0.0027 \\
\hline & \multicolumn{3}{|c|}{$(0.00099)$} & $(0.0020)$ \\
\hline \multicolumn{5}{|l|}{ Conservative party (ref) } \\
\hline \multirow[t]{2}{*}{ Labour } & \multicolumn{3}{|c|}{-0.023} & -0.025 \\
\hline & \multicolumn{3}{|c|}{$(0.020)$} & $(0.021)$ \\
\hline \multirow[t]{2}{*}{ Coalition } & \multicolumn{3}{|c|}{-0.014} & -0.022 \\
\hline & \multicolumn{3}{|c|}{$(0.022)$} & $(0.029)$ \\
\hline \multirow[t]{2}{*}{ Whig/Liberal } & \multicolumn{3}{|c|}{-0.041} & -0.046 \\
\hline & \multicolumn{3}{|c|}{$(0.027)$} & $(0.027)$ \\
\hline \multirow{2}{*}{$\begin{array}{l}\text { Increase in public debt } \\
\text { (\%GDP) }\end{array}$} & & \multirow{2}{*}{\multicolumn{2}{|c|}{$\begin{array}{l}-0.000057 \\
(0.00062)\end{array}$}} & 0.00063 \\
\hline & & & & $(0.00093)$ \\
\hline \multirow{2}{*}{$\begin{array}{l}\text { Increase in tax revenues } \\
\text { (\%GDP) }\end{array}$} & & \multirow{2}{*}{\multicolumn{2}{|c|}{$\begin{array}{l}-0.0035 \\
(0.0050)\end{array}$}} & -0.0012 \\
\hline & & & & $(0.0058)$ \\
\hline \multirow{2}{*}{$\begin{array}{l}\text { Increase in non-defence government } \\
\text { spending (\%GDP) }\end{array}$} & & \multirow{2}{*}{\multicolumn{2}{|c|}{$\begin{array}{l}0.012^{* * * *} \\
(0.0030)\end{array}$}} & 0.0073 \\
\hline & & & & $(0.0054)$ \\
\hline \multirow[t]{2}{*}{ Constant } & -0.0069 & 0.0062 & -0.0083 & 0.0076 \\
\hline & $(0.0085)$ & $(0.014)$ & $(0.0080)$ & $(0.015)$ \\
\hline Observations & 105 & 105 & 100 & 100 \\
\hline
\end{tabular}

Notes: ${ }^{*} \mathrm{p}<0.05,{ }^{* *} \mathrm{p}<0.01,{ }^{* * *} \mathrm{p}<0.001$. Standard errors are in parenthesis. All models estimated using Newey-West standard errors which are adjusted for heteroscedasticity and serial correlation up to the second lag. Descriptive statistics for control variables in Web Appendix 2. 
This analysis provides evidence for the 'Malthusian' hypothesis. Rising unemployment is positively correlated with rising stigmatising rhetoric even after accounting for the number of articles published in that year (Model 1: Table 2). Other variables may potentially explain this relationship: in figure 1 unemployment and stigmatising rhetoric both dramatically decline during WWI and WWII and so we include government spending on defence (\% of GDP) in our models (Mitchell, 2007), but this does not substantively alter our main finding (Model 2: Table 2). Political factors, such as the party in power, may shape media rhetoric during times of rising unemployment through their 'agenda-setting' capacity (Tyler, 2013). However, we see no clear change in our results once we control for the political party composition of government (Model 2: Table 2). See web appendix 4 for evidence that these results are robust to alternative measures of wartime, and controls for election year.

The health of public finances is another possible confounder: during the Great Recession conservative media often blamed welfare recipients for high levels of public sector debt. Therefore we add measures of public debt, tax revenue, and non-defence public spending, all as a proportion of GDP, to our models (Thomas and Dimsdale, 2016). The coefficient on unemployment remains positive and statistically significant, although there is some evidence that increased non-defence public spending is associated with increased stigmatising rhetoric. Taken together, the stability of our regression results offer further evidence in favour of the 'Malthusian' hypothesis that stigmatising rhetoric becomes more common when unemployment rises.

WHY DOES THE RELATIONSHIP BETWEEN UNEMPLOYMENT AND STIGMATISING RHETORIC WEAKEN IN THE 1930S AND 1980S?

Figure 1 shows that the association between unemployment and negative rhetoric breaks down in periods of especially high unemployment rates, potentially suggesting some non-linearity in the association between unemployment and stigmatising rhetoric. Stigmatising rhetoric may not increase with rising unemployment if the starting level of unemployment is already very high.

To test this we re-estimate model 1 from table 2 with an interaction between the change in the unemployment rate and the level of unemployment (see Box 1, web appendix 5 for details). Figure 2 plots the estimated effect of a $1 \%$ increase in unemployment on changes in negative rhetoric, at a variety of different starting levels of unemployment. A $1 \%$ increase in unemployment is associated with a greater increase in stigmatising rhetoric when the initial level of unemployment is low. At higher rates of unemployment the effect of an increase in unemployment on stigmatising rhetoric gets smaller. At levels of unemployment above $7 \%$ the association between change in unemployment and stigmatising rhetoric is not significantly different from 0 . In fact, at very high levels of unemployment, an additional increase in unemployment - for example, from $13 \%$ to $14 \%$ - may even reduce the amount of stigmatising rhetoric (although the confidence intervals cover 0 ). This is the situation we see in the early 1930s when the use of stigmatising rhetoric falls once unemployment rates became exceptionally high. 
Figure 2: Increases in unemployment are associated with increases in stigmatising rhetoric only when the level of unemployment is low

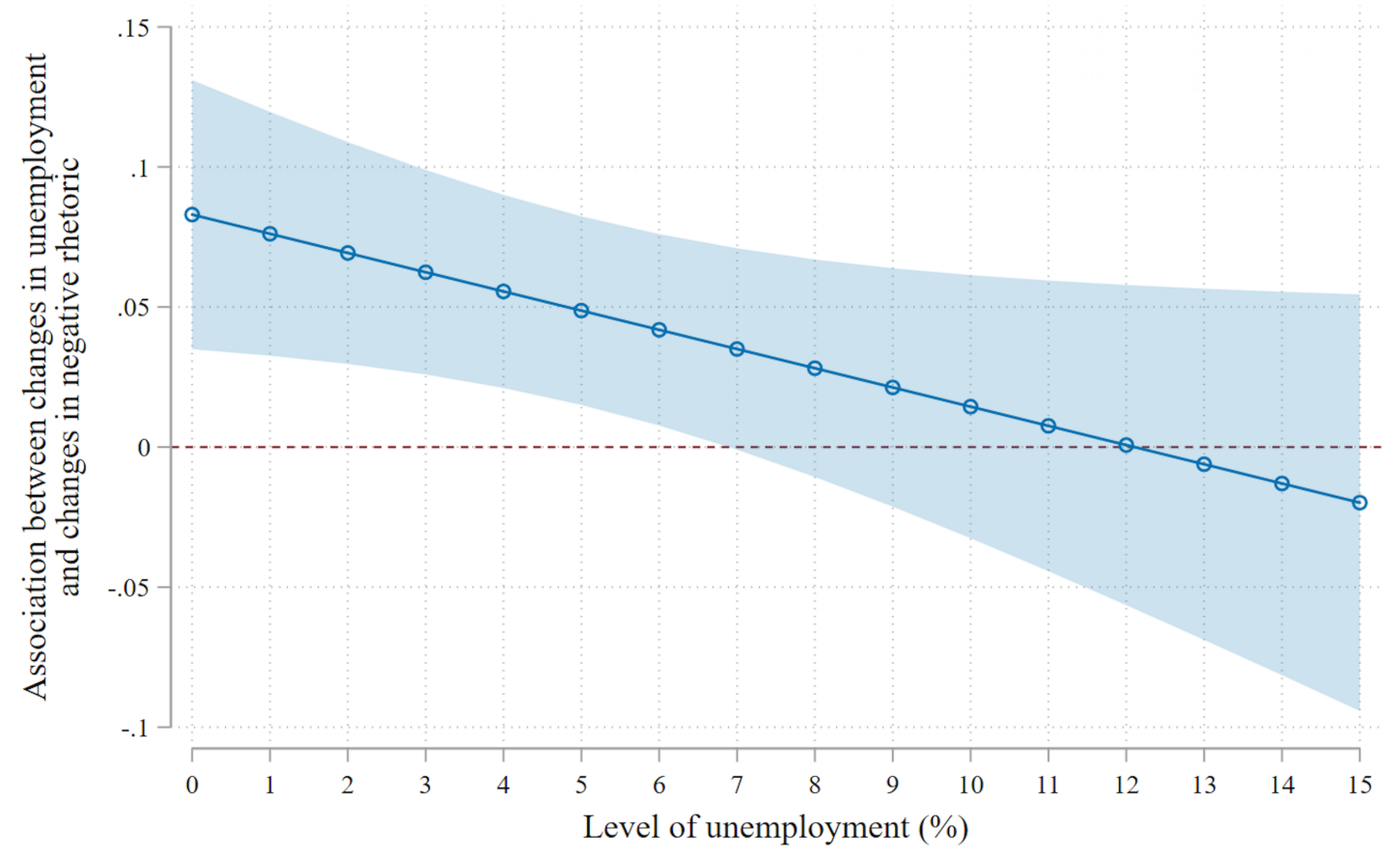

Notes: We estimate the change in stigmatising rhetoric associated with a $1 \%$ increase in unemployment given the pre-existing level of unemployment. While an unemployment of 0 is strictly outside of our sample, there are years when unemployment rates are very low (0.1\%). Model coefficients in web appendix 5 .

\section{IS RISING UNEMPLOYMENT ASSOCIATED WITH CHANGES IN WORDS UNRE- LATED TO POVERTY?}

It is possible that the association between unemployment and stigmatising rhetoric could be spurious and driven by some unobserved factor that affects the words newspapers use unrelated to changes in unemployment rates. We explore this possibility by testing whether our measure of unemployment is correlated with a set of placebo words that we would not theoretically expect to be correlated with changes in unemployment. Using the same data and method described above (see Box 1), we construct a sample of 12 commonly-used words in four categories: historical figures (Shakespeare, Mozart), past-times (football, cricket, opera, theatre), countries (France, Germany, America), and rooms of the house (bedroom, bathroom, kitchen). We hypothesise that changes in the logged frequency of these 'placebo' words should not be associated with changes in logged unemployment rates. If they were, this would raise serious doubts about our argument. Table 3 replicates models from Table 2 with logged mean frequency of placebo words as the dependent variable. In each model the relationship is positive 
but statistically insignificant. Moreover, the size of the association is far smaller. For example, in the fully adjusted models (models 4 in tables 2 and 3), the coefficient for stigmatising rhetoric $(\delta$ stigmatising $=0.033)$ is 10 times larger than the coefficient for the placebo words $(\delta$ placebo $=$ 0.0031). These models increase our confidence that the relationship between unemployment and stigmatising rhetoric is not spurious.

Table 3: Association between unemployment rate and placebo words adjusting for covariates, $1896-2000$

\begin{tabular}{|c|c|c|c|c|}
\hline & \multicolumn{4}{|c|}{$\begin{array}{l}\text { Annual change in the average frequency of } \\
\text { placebo words }\end{array}$} \\
\hline & (1) & (2) & (3) & (4) \\
\hline Increase in the unemployment & 0.025 & 0.020 & 0.013 & 0.0031 \\
\hline rate $(\log )$ & $(0.017)$ & $(0.014)$ & $(0.013)$ & $(0.011)$ \\
\hline Increase in the number of & $0.71^{* * *}$ & $0.67^{* * *}$ & $0.81^{* * *}$ & $0.75^{* * *}$ \\
\hline published articles $(\log )$ & $(0.13)$ & $(0.13)$ & $(0.10)$ & $(0.11)$ \\
\hline \multirow[t]{2}{*}{ Defence spending (\%GDP) } & & -0.0018 & & -0.0027 \\
\hline & & $(0.0012)$ & & $(0.0018)$ \\
\hline \multicolumn{5}{|l|}{ Conservative party (ref) } \\
\hline \multirow[t]{2}{*}{ Labour } & & -0.020 & & -0.022 \\
\hline & & $(0.013)$ & & $(0.013)$ \\
\hline \multirow[t]{2}{*}{ Coalition } & & -0.013 & & -0.022 \\
\hline & & $(0.017)$ & & $(0.019)$ \\
\hline \multirow[t]{2}{*}{ Whig/Liberal } & & -0.0088 & & -0.016 \\
\hline & & $(0.016)$ & & $(0.017)$ \\
\hline \multirow[t]{2}{*}{ Increase in public debt (\%GDP) } & & & 0.00028 & 0.00096 \\
\hline & & & $(0.00042)$ & $(0.00061)$ \\
\hline \multirow[t]{2}{*}{ Increase in tax revenues (\%GDP) } & & & -0.0016 & 0.00076 \\
\hline & & & $(0.0027)$ & $(0.0029)$ \\
\hline Increase in non-defence government & & & 0.0012 & -0.0028 \\
\hline spending (\%GDP) & & & $(0.0020)$ & $(0.0030)$ \\
\hline \multirow[t]{2}{*}{ Constant } & 0.0030 & 0.012 & 0.0032 & 0.016 \\
\hline & $(0.0065)$ & $(0.0090)$ & $(0.0057)$ & $(0.0083)$ \\
\hline Observations & 105 & 105 & 100 & 100 \\
\hline
\end{tabular}

Notes: ${ }^{*} \mathrm{p}<0.05,{ }^{* *} \mathrm{p}<0.01,{ }^{* * *} \mathrm{p}<0.001 .$. Standard errors are in parenthesis. All models estimated using Newey-West standard errors which are adjusted for heteroscedasticity and serial correlation up to the second lag. Descriptive statistics for control variables in Web Appendix 2. 


\section{ARE OUR RESULTS ROBUST TO MEASUREMENT ERROR?}

Measuring stigmatising rhetoric about the poor by counting the number of times particular words or phrases are used will necessarily entail measurement error. In this section we explore whether and how measurement error may bias our results.

We first investigate whether a few specific words are driving our results by estimating regression models where the frequency of each individual word is treated as a separate response variable. Figure 3 presents the association between logged unemployment rates and each of the 28 words we use to measure stigmatising rhetoric (see table 1). ${ }^{6}$ Of the thirty-two words analysed, thirty (94\%) have positive associations with unemployment - meaning they are used more often in years when unemployment is higher. Moreover, the confidence intervals around the coefficient for logged unemployment do not include zero for twenty-eight of the thirty-two words (88\%). The vast majority of the stigmatising words in our sample are used with higher frequencies in years with higher levels of unemployment, providing evidence their usage is driven by a common underlying process.

Frequency of word use is an imperfect measure of stigmatising rhetoric because all of the words used in this analysis are polysemic, even if they are primarily recognisable as words associated with poverty. Ambiguity of meaning creates some uncertainty in our results: perhaps the correlations we observe are driven by uses of words that are unrelated to poverty. To address this concern, we conduct a content analysis of newspaper articles in years where our regression model fits well (i.e. typical cases) and years where our model fits poorly (i.e. deviant cases). Typical case analysis is primarily confirmatory - exploring whether the words and phrases used in our measure of stigmatising rhetoric are in fact being deployed in a poverty-related context. Deviant case analysis, however, is particularly good at discovering measurement error or omitted variables (Seawright, 2016).

We identify two typical (1901 and 1991) and two deviant (1934 and 1980) cases using the absolute value of the residuals from model 1 in table 2 and we selected words for further analysis based on whether they were rising in that year or were unusually elevated in that period. We also chose a variety of words to ensure our results are not driven by idiosyncrasies of any particular term. In each year, we read the first 100 randomly selected articles or, if there were fewer than 100 articles, we read every article. The second author then coded each usage of each word according to whether the word was used in reference to the poor (if it was not it was classed as 'irrelevant') and if the word was used in reference to the poor we then determined whether the word was used in a stigmatising, sympathetic, or neutral way. The first author also coded half of these cases to check intercoder reliability. We provide some illustrative examples of this coding in table 4. Further details are provided in Web Appendix 6, including statistics on intercoder reliability.

\footnotetext{
${ }^{6}$ Negative binomial models for overdispersed count data are used, with the total number of articles treated as an exposure variable. Serial correlation is corrected for with Newey-West standard errors, and a linear time trend included. Note that this analysis examines levels of unemployment and frequency of word usage rather than changes.
} 
Figure 3: Association between unemployment and the frequency of stigmatising words or phrases, 1896-2000

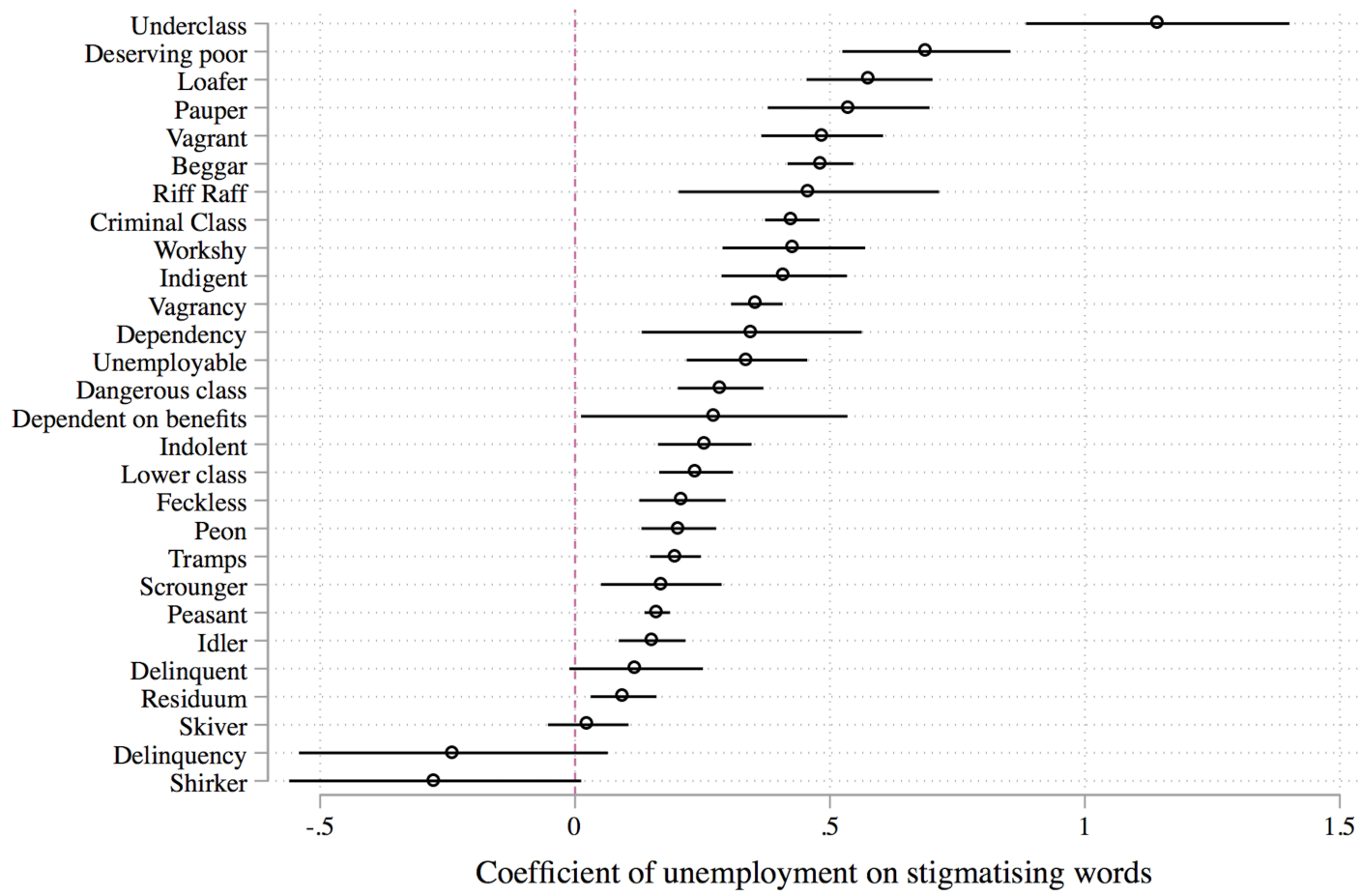

Notes: Each point estimate and 95\% confidence interval comes from a different regression model. All models are negative binomial regression models which adjusts for over-dispersion using the total number of articles published in a given year. We use Newey-West standard errors to adjust for serial correlation and heteroscedasticity.

Table 4: Examples of newspaper word usage by relevance and sentiment

\begin{tabular}{|c|c|c|c|}
\hline Stigmatising/Negative & Sympathetic/Positive & Neutral & Irrelevant \\
\hline $\begin{array}{l}\text { 'A family of paupers, } \\
\text { extending to three } \\
\text { generations, has cost } \\
\text { the ratepayers of the } \\
\text { Paddington Union a } \\
\text { sum of } £ 3,000 ’ \\
\text { (Hereditary Pauperism, } \\
\text { Daily Mail, } \\
21 / 11 / 1901 \text { ) }\end{array}$ & $\begin{array}{c}\text { 'A pathetic letter, } \\
\text { which throws a flood } \\
\text { of light on the terrible } \\
\text { monotony of life in a } \\
\text { workhouse' (A day in a } \\
\text { Pauper's Life, Daily } \\
\text { Mail, 29/10/ 1901) }\end{array}$ & $\begin{array}{l}\text { 'Mr How is highly } \\
\text { educated, and spends } \\
\text { most of his time } \\
\text { travelling about the } \\
\text { country, mixing with } \\
\text { tramps and other } \\
\text { outcasts' (A Pauper } \\
\text { Millionaire, Daily Mail, } \\
\text { 9/10/1901) }\end{array}$ & $\begin{array}{l}\text { 'The man found dead } \\
\text { under a hedge... and } \\
\text { since buried in a } \\
\text { pauper's grave, was } \\
\text { John Howard Bullheid' } \\
\text { (Solicitor's Strange } \\
\text { Death, Daily Telegraph, } \\
\text { 9/10/ 1901) }\end{array}$ \\
\hline
\end{tabular}




\begin{tabular}{|c|c|c|c|}
\hline $\begin{array}{c}\text { 'Gangs of drunken } \\
\text { beggars... aggressive } \\
\text { vagrants' (Menace of } \\
\text { the beggars who strike } \\
\text { fear in heart of } \\
\text { London, Daily Mail, } \\
17 / 6 / 1991 \text { ) }\end{array}$ & $\begin{array}{l}\text { 'An underclass is } \\
\text { formed by a physical } \\
\text { concentration of social } \\
\text { problems' (The } \\
\text { Underclass is no } \\
\text { Illusion, Financial } \\
\text { Times, } 22 / 4 / 1991 \text { ) }\end{array}$ & $\begin{array}{l}\text { 'His chosen descent } \\
\text { into the underworld of } \\
\text { the workless and } \\
\text { vagrant' (Making it } \\
\text { seem virtuous to eat } \\
\text { bacon, Daily Telegraph, } \\
\text { 19/10/1991) }\end{array}$ & $\begin{array}{c}\text { 'Jimmy finds a vagrant } \\
\text { who has moved in' (TV } \\
\text { Listing for Casualty, } \\
\text { 8/11/1991) }\end{array}$ \\
\hline
\end{tabular}

The typical case analysis confirms our main findings, but it also highlights some of the challenges with this approach to measuring stigmatising rhetoric. Both 'pauper' and 'underclass' were almost always used in relation to issues of poverty but this was not always true of 'loafer' and 'vagrant', where around $40 \%$ of mentions were not directly related to poverty. Importantly, of the uses of 'loafer' and 'vagrant' that pertain to poverty, the majority are negative (40\%-50\%, compared to $0 \%-18 \%$ that are sympathetic). This suggests that increases in stigmatising words are a good measure of increasing stigmatising rhetoric, and do not simply capture increasing discussion of poverty in general at times of high unemployment.

The deviant case analysis brings out a different but equally important perspective. In those years where our model fits poorly there are a higher number (30\%-70\% of all uses) of 'irrelevant' uses of tramp (e.g., 'tramp shipping'), beggar (e.g., 'The Beggar's Opera'), and workshy (e.g., the name of a race-horse). These cases fit our model poorly because the words are not being used to describe the poor at all, confirming the presence of measurement error in our dependent variable (Seawright, 2016).

Our content analysis of typical and deviant cases provides additional evidence supporting the 'Malthusian' hypothesis that stigmatising rhetoric increases when unemployment rises. Counting word frequencies is not a perfect strategy for measuring negative rhetoric. It clearly captures both signal (uses of the words in relation to poverty) and noise. The noise that we measure, however, seems more likely to be random (uses of the words unrelated to poverty) rather than biasing our results.

\section{DISCUSSION}

This analysis draws on a dataset measuring how often five centrist and right-wing newspapers used stigmatising language about people in poverty across the twentieth century. Case studies of media rhetoric have often argued that the poor are stigmatised more by the media during recessions because the media frame unemployment through a Malthusian lens (Harkins and Lugo-Ocando, 2016). Consistent with this argument, we find that when unemployment increases so too does the frequency of stigmatising rhetoric about the poor. This association is not explained by other political, economic, or fiscal variables. Our content analysis of articles suggest that the words we selected are used in a predominantly stigmatising or negative way in years where unemployment is increasing. 
Figure 4: Trends in the frequency of stigmatising rhetoric and welfare attitudes in the UK

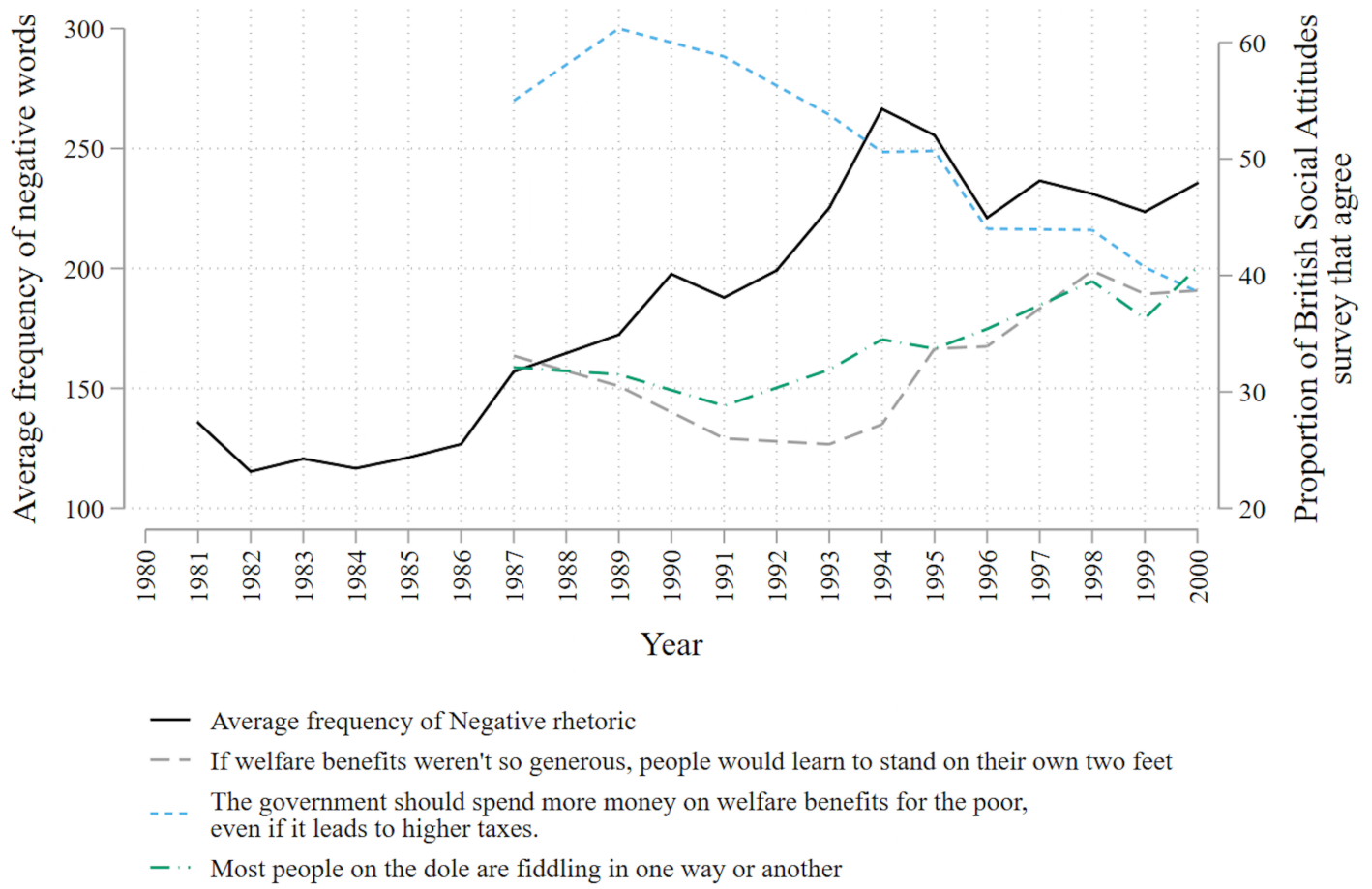

Notes: Public opinion data from the British Social Attitudes Survey 1987-2000.

\section{STIGMA AND ATTITUDES TOWARD PEOPLE ON BENEFITS}

One possible consequence of the recurrent stigmatisation of the poor is its effect on public attitudes toward people in poverty and welfare recipients. Media framings have a great deal of power to 'construct' and 'normalise' certain ways of viewing poverty (Gamson et al., 1992). Unfortunately, data on public opinion toward welfare is too sparse before the 1980s to systematically investigate whether shifts in media rhetoric influenced attitudes (Hudson et al., 2016). Looking just at attitudinal shifts towards welfare recipients since the start of the British Social Attitudes Survey (covering 1987-2000), we find increasing stigmatising rhetoric about welfare recipients in the media during the late-1980s and 1990s appears to have preceded increasingly negative social attitudes (figure 4). This trend is consistent with a wide body of empirical evidence documenting the effect of the media on attitudes (King et al., 2017) and political outcomes, like voting (Reeves et al., 2016).

\section{CAUSALITY, MECHANISMS, AND MEDIA PRODUCTION}

The temporal reach of our analysis allows us to avoid relying on case studies of specific periods when media stigmatisation of the poor was highly salient. Our modelling attempts to address both long-term confounding through first differencing, and short-term confounding through 
our control variables- a strategy which is reinforced by our placebo analyses. However, we are still cautious about a causal interpretation of our results, in part because of the usual difficulties involved in causal inference from observational data, but also because the account we provide does not fully specify or test the mechanisms involved in producing articles about people in poverty. The content and tone of newspaper articles are determined by a complex set of interactions among journalists, editors, newspaper proprietors, and the perceived or actual response of readers; these are processes our results do not address (Gamson et al., 1992; Golding and Middleton, 1982; Herman and Chomsky, 1994).

An additional reason for caution is that our theory does not fully account for those periods when the relationship between unemployment and stigmatising rhetoric weakens. When unemployment is already very high (e.g., 1930s and 1980s) then further increases in joblessness do not necessarily lead to more stigmatising language. One possible explanation is that structural understandings of poverty may become more plausible in periods when unemployment is exceptionally high and it becomes difficult to blame the moral failings of the unemployed. It is also possible the economic situation of journalists might affect the content of their articles. If journalists become at particular risk of losing their jobs during extremely deep recessions they might become more sympathetic towards the poor.

Given these caveats, we argue future research should trace how processes of media production affect the way people in poverty are presented. This work could deploy detailed discourse analysis or archival research to unpick how actors such as proprietors or editors shape journalistic decisions about how to cover stories about poverty, and how they respond to changing economic conditions (Baker, 2007).

\section{HISTORY, CONTEXT, AND IDEATIONAL EMBEDDEDNESS}

One insight we gain from our historical approach is the degree to which Malthusian explanations of poverty have become 'ideationally embedded' in British politics and culture (Somers and Block, 2005). The very fact that we observe a relatively stable association between rising unemployment and the frequency of stigmatising rhetoric is indicative of how particular ideational regimes are redeployed to 'construct, ... explain, and normalise market processes', particularly in moments of 'crisis' when the logic of Malthusianism might be dislodged by some other 'more compelling public narrative' (Somers and Block, 2005: 264, 271). For example, the experience of personal or family unemployment may lead individuals to support greater redistribution if they are not countered by a narrative that blames the crisis on the immoral behaviour of the poor. The ideational embeddedness of Malthusian ideas may help us explain why people living in poverty are to deploy stigmatising language themselves: their interpretation of the social world is framed by, and draws on, the same set of narratives, symbols, and discourses.

Our paper has broader theoretical relevance beyond poverty stigma because it provides an account of the conditions under which deeply embedded cultural understandings are differentially activated when they resonate with the structural context. This theoretical apparatus, when combined with our long historical focus might prove useful for understanding the resur- 
gence of anti-immigrant sentiment and nationalism in the press, and how these trends may reflect longer processes connected with imperialism, decolonisation, and mass immigration to the UK (Bonikowski, 2017).

\section{LIMITATIONS}

Error in our measure of stigmatising rhetoric is a limitation of our analysis. There will be occasions when we count the usage of a word as 'stigmatising' even though it is being used in another context; this issue is exacerbated by the way that the language used to talk about poverty changes over time. However, our content analysis suggested that measurement error predominantly occurred in years where model fit was poor, implying that error in our measure of stigmatising language likely undermines our ability to observe a relationship between economic conditions and stigmatising rhetoric. Another concern is the generalisability of our results, which are limited because the archive used in our analysis only provides access to a set of centrist and right-wing publications. We cannot draw any conclusions about how left-wing papers respond to rising unemployment. We are also unable to address the extent to which journalists are responding to the attitudes of their readers. While we cannot rule out this possibility entirely, it is unlikely during the first three quarters of the twentieth century because newspapers did not have access to regular and consistent polling data on the attitudes of their readers towards welfare recipients (Hudson et al., 2016). This may change in the future as such data has now become far more readily available.

\section{CONCLUSION}

The rise in stigmatising media rhetoric about the poor following the Great Recession was consistent with a pattern we observe across the twentieth century: as unemployment increases so does newspaper stigmatisation of the poor. Although our data ends during the earliest years of New Labour, there is little reason to expect that much has changed since then. The Blair government presented itself as no soft touch on welfare, a trend that was only amplified by the Conservative-led coalition. The Cameron government attacked 'scroungers' and 'skivers', language that was also picked up by newspapers (Jensen and Tyler, 2015). The phenomenon of 'poverty porn' too is symptomatic of the ideational embeddedness of Malthusian ideas, revealing how producers, viewers, and, to some extent, subjects of these 'documentaries' draw on and reproduce these narratives (Jensen, 2014). These ideas are deeply rooted in the British cultural imagination and so such language will return in the future, likely in a different form, but with the same purpose of 'holding dependent poverty disgraceful' (Malthus, 2008: III.VI.5). Though the specific words used might vary, the rhetoric of recessions among centre-right British newspapers is unlikely to change in the near future. 
Acknowledgments We would like to thank Imogen Tyler, Jonathan Mijs, Robert de Vries, and the members of the LSE's writing group in the Sociology Department for helpful comments on earlier versions of this paper. We would also like to acknowledge the reviewers and editor at Sociology, whose comments have helped us to improve the paper.

Funding Aaron Reeves was supported by the Joseph Rowntree Foundation's programme on poverty and inequality for this project. Daniel McArthur was supported by an ESRC PhD studentship during the writing of this paper. The funders had no influence on the design of this study, the interpretation of the results, or the decision to publish.

Daniel MacArthur is a PhD candidate in the London School of Economics Sociology Department and International Inequalities Institute. His thesis, entitled 'Economic position, inequality, and the stigmatisation of poverty and welfare receipt' uses British and European survey data to examine the economic conditions under which individuals believe that the poor are to blame for their situation. He is involved in collaborative research projects on the effects of school rankings on the geographical concentration of poverty, the causes of poverty among foodbank users, and the relationship between unemployment rates and the presentation of the poor in British newspapers.

Aaron Reeves is Associate Professorial Research Fellow in the International Inequalities Institute at the London School of Economics and Associate Professor in the Department of Social Policy and Intervention at the University of Oxford. His research is focused on understanding the causes and consequences of social, economic, and cultural inequality across countries. 


\section{REFERENCES}

Baker CE (2007) Media Concentration and Democracy: Why Ownership Matters. Cambridge: Cambridge University Press.

Benford RD and Snow DA (2000) Framing Processes and Social Movements: An Overview and Assessment. Annual Review of Sociology 26: 611-639.

Bonikowski B (2017) Ethno-Nationalist Populism and the Mobilization of Collective Resentment. The British Journal of Sociology 68(S1): 181-213.

Bourdieu P (1998) Acts of resistance : against the new myths of our time. Cambridge: Polity.

Couldry N and Hepp A (2016) The Mediated Construction of Reality. Cambridge, UK: Polity Press.

Day G (2001) Class. London: Routledge.

Deacon A (1976) In Search of the Scrounger: The Administration of Unemployment Insurance in Britain, 1920-1931. London: Bell for the Social Administration Research Trust.

Drage G (1894) The Unemployed. London: Macmillan and company.

Gamson WA (1992) Talking Politics. Cambridge: UK: Cambridge University Press.

Gamson WA and Lasch KE (1983) The political culture of social welfare policy. In: Spiro SE and Yuchtman-Yaar E (eds.) Evaluating the Welfare State: Social and Political Perspectives. London: Academic Press.

Gamson WA, Croteau D, Hoynes W, et al. (1992) Media Images and the Social Construction of Reality. Annual Review of Sociology 18: 373-393.

Gilens M (1996) Race and Poverty in America: Public Misperceptions and the American News Media. The Public Opinion Quarterly 60(4): 515-541.

Golding P and Middleton S (1982) Images of Welfare: Press and Public Attitudes to Poverty. Oxford: M. Robertson.

Harkins S and Lugo-Ocando J (2016) How Malthusian ideology crept into the newsroom: British tabloids and the coverage of the 'underclass.' Critical Discourse Studies 13(1): 78-93.

Herman ES and Chomsky N (1994) Manufacturing Consent: The Political Economy of the Mass Media. London: Vintage.

Hudson J, Lunt N, Hamilton C, et al. (2016) Nostalgia narratives? Pejorative attitudes to wel- 
fare in historical perspective: survey evidence from Beveridge to the British Social Attitudes Survey. Journal of Poverty and Social Justice 24(3): 227-43.

Jensen T (2014) Welfare Commonsense, Poverty Porn and Doxosophy. Sociological Research Online 19(3): 3.

Jensen T and Tyler I (2015) 'Benefits broods': The cultural and political crafting of anti-welfare commonsense. Critical Social Policy 35(4): 470-491.

King G, Schneer B and White A (2017) How the news media activate public expression and influence national agendas. Science 358(6364): 776-780.

Lansdall-Welfare T, Sudhahar S, Thompson J, et al. (2017) Content analysis of 150 years of British periodicals. Proceedings of the National Academy of Sciences 114(4): E457-E465.

Lister R (2015) “To count for nothing”: Poverty beyond the statistics. Journal of the British Academy 3: 139-165.

Macdonald R, Shildrick T and Furlong A (2014) In search of "intergenerational cultures of worklessness": Hunting the Yeti and shooting zombies. Critical Social Policy 34(2): 199-220.

Macnicol J (1987) In Pursuit of the Underclass. Journal of Social Policy 16(3): 293-318.

Macnicol J (1998) Perspectives on the Idea of an “Underclass." In: Edwards J and Revauger J-P (eds.) Discourses on Inequality in France and Britain. Aldershot, U.K.: Ashgate, pp. 161-74.

Malthus T (2008) An Essay on the Principle of Population. Gilbert G (ed.). Oxford ; New York: OUP Oxford.

McKendrick JH, Sinclair S, Irwin A, et al. (2008) The media, poverty and public opinion in the UK. York: Joseph Rowntree Foundation.

Misra J, Moller S and Karides M (2003) Envisioning Dependency: Changing Media Depictions of Welfare in the 20th Century. Social Problems 50(4): 482-504.

Mitchell B (2007) International Historical Statisics 1750-2005: Europe. 6th ed. Houndsmills, Basingstoke, Hampshire: Palgrave Macmillan.

Polanyi K (2002) The Great Transformation: The Political and Economic Origins of Our Time. 2nd edition. Boston, MA: Beacon Press.

Reeves A and de Vries R (2016) Does media coverage influence public attitudes towards welfare recipients? The impact of the 2011 English riots. British Journal of Sociology 67(2): 281-306.

Reeves A, McKee M and Stuckler D (2016) 'It's The Sun Wot Won It': Evidence of media in- 
fluence on political attitudes and voting from a UK quasi-natural experiment. Social Science Research 56: 44-57.

Rose M and Baumgartner FR (2013) Framing the Poor: Media Coverage and U.S. Poverty Policy, 1960-2008. Policy Studies Journal 41(1): 22-53.

Seawright J (2016) The Case for Selecting Cases That Are Deviant or Extreme on the Independent Variable. Sociological Methods and Research 45(3): 493-525.

Shildrick T and MacDonald R (2013) Poverty talk: how people experiencing poverty deny their poverty and why they blame 'the poor.' The Sociological Review 61(2): 285-303.

Somers MR and Block F (2005) From Poverty to Perversity: Ideas, Markets, and Institutions over 200 Years of Welfare Debate. American Sociological Review 70(2): 260-287.

Thomas R and Dimsdale N (2016) Three Centuries of Data - Version 3.0. Bank of England. Available at: http://www.bankofengland.co.uk/research/Pages/onebank/threecenturies.aspx.

Tyler I (2008) “Chav Mum Chav Scum.” Feminist Media Studies 8(1): 17-34.

Tyler I (2013) Revolting Subjects: Social Abjection and Resistance in Neoliberal Britain. 1 edition. London, UK: Zed Books.

van Oorschot W (2006) Making the difference in social Europe: deservingness perceptions among citizens of European welfare states. Journal of European Social Policy 16(1): 23-42.

Welshman J (2007) Underclass: A History of the Excluded, 1880 - 2000. New Ed edition. London: Continuum International Publishing. 


\section{WEB APPENDIX}

Web Appendix 1: Circulation figures, political leaning, readership demographics, and ownership details of selected newspapers

Web Appendix 2: Descriptive statistics for dependent, independent, and control variables

Web Appendix 3: Addressing autocorrelation

Web Appendix 4: Robustness of relationship between unemployment and negative rhetoric to alternate controls for war and defence spending and general elections

Web Appendix 5: How the relationship between changes in unemployment and changes in stigmatising rhetoric depend on starting levels of unemployment

Web Appendix 6: Typical and deviant case selection 


\section{Web ApPendix 1: CiRCULATION FIgURES, POLITICAL LEANING, READERSHIP DEMOGRAPHICS, AND OWNERSHIP DETAILS OF SELECTED NEWSPAPERS}

This appendix provides additional detail about our sample of newspapers. Most of the data presented here is not available for the Economist as it is usually classed as a weekly news magazine rather than a newspaper (though it self-describes as a newspaper). In terms of readership demographics and political leanings it is likely to be similar to the Financial Times.

\section{Political leanings}

Our sample of papers are predominantly centrist or right-wing in orientation. The Daily Mail and Daily Telegraph have both been staunchly conservative since their founding (Temple, 2008: 34-9), and have backed the British Conservative Party at every election from 1945 onwards (Butler and Butler, 2000: 536). The Times also usually endorses the Conservative Party, while the Economist and Financial Times tend more towards classical liberal concerns about free trade and markets.

\section{Circulation}

Table 1a displays circulation information for the daily (rather than Sunday) editions of the Mail, Telegraph, Times, and Financial Times. In terms of circulation, the Daily Mail and Telegraph reach a mass market, with circulations of over 1 million a day for much of the 20th century, as table 1a illustrates. The Times and Financial Times perhaps make up for their smaller circulations by their reputation for reaching and influencing political and economic elites. Excluding the Economist, our sample of papers consistently reach about 3-4 million readers in the post-war period, which comprises about a quarter of the total circulation of national daily newspapers, and between one quarter and half of all papers published consistently across the 20th century.

Table 1a: circulation for our sample of newspapers

\begin{tabular}{cccccccc}
\hline \hline \multicolumn{7}{c}{ Circulation in 000s } \\
\hline Year & $\begin{array}{c}\text { Daily } \\
\text { Mail }\end{array}$ & $\begin{array}{c}\text { Daily } \\
\text { Telegraph }\end{array}$ & Times & $\begin{array}{c}\text { Financial } \\
\text { Times }\end{array}$ & Total & $\begin{array}{c}\text { \% of total } \\
\text { circulation }\end{array}$ & $\begin{array}{c}\text { \% circulation of } \\
\text { consistently } \\
\text { published }\end{array}$ \\
\hline 1910 & 900 & 230 & 45 & & 1175 & $27 \%$ & $52 \%$ \\
1930 & 1986 & 222 & 187 & & 2395 & $27 \%$ & $41 \%$ \\
1939 & 1510 & 640 & 213 & & 2363 & $22 \%$ & $29 \%$ \\
1951 & 2245 & 976 & 254 & 57 & 3532 & $21 \%$ & $24 \%$ \\
1960 & 2084 & 1155 & 255 & 122 & 3616 & $22 \%$ & $26 \%$ \\
1965 & 2464 & 1351 & 258 & 146 & 4219 & $27 \%$ & $29 \%$ \\
1970 & 1917 & 1402 & 402 & 170 & 3891 & $33 \%$ & $35 \%$ \\
1980 & 1985 & 1456 & 316 & 196 & 3953 & $26 \%$ & $28 \%$ \\
1990 & 1708 & 1076 & 420 & 290 & 3494 & $25 \%$ & $28 \%$ \\
1998 & 2343 & 1062 & 760 & & 4165 & $33 \%$ & $35 \%$ \\
\hline \hline
\end{tabular}

Notes: all circulation figures in 000s. Figures originate from a variety of sources collected in Butler and Butler (2000: 536-8) except Financial Times (Seymour-Ure, 2000: 28-9). No data is available for the Financial Times prior to 1951 because it was not regarded as a national newspaper due to its' narrow focus on finance. 


\section{Readership Demographics}

Newspaper readership is closely associated with occupational status (Chan and Goldthorpe, 2007). The Telegraph, Financial Times, and Times, all belong to the so-called 'broadsheet' or 'quality' press aimed at high status professional and managerial classes, while the Daily Mail is usually seen as a 'mid-market tabloid' appealing to a lower-middle class/ intermediate status audience. Table $1 \mathrm{~b}$ confirms these conclusions, for the post-war era at least $-40-50 \%$ of the readership of the Telegraph, Financial Times, and Times come from the professional and managerial classes, and fewer than 10\% (except for the Times in 1966) from the semi and unskilled manual classes. By contrast, the Daily Mail draws a similar proportion of readers from these two classes. Thus our sample of newspapers is read generally by relatively advantaged groups, with the exception of the Mail, which has always tended to have a broader appeal (Temple, 2008: 28-9).

Table 1b: Percentage of newspaper readership in NRS Social Grade $\mathrm{AB}$ - professional, administrative, and managerial, $\mathrm{DE}$ - semi and unskilled manual.

\begin{tabular}{lcccccc}
\hline \hline & \multicolumn{4}{c}{1966} & \multicolumn{3}{c}{$1993-4$} \\
& AB & DE & difference & AB & DE & difference \\
\hline Daily Mail & 19 & 27 & -8 & 30 & 16 & 14 \\
Daily Telegraph & 42 & 8 & 34 & 55 & 7 & 48 \\
Financial Times & 56 & 3 & 53 & 61 & 4 & 57 \\
Times & 54 & 15 & 39 & 60 & 7 & 53 \\
\hline \hline
\end{tabular}

Notes: data from the National Readership Survey, tabulated in Seymour-Ure (2000: 144-5)

\section{Ownership}

Media theorists often regard newspaper proprietors as having a major influence on the output and tone of newspapers. The Daily Mail, Daily Telegraph, and Times (including Sunday editions) are owned by privately owned companies on behalf of wealthy proprietors 'press barons' (for example Rupert Murdoch's News International have owned the Times since 1981). This ownership model has persisted since the founding of all three papers, with fairly few changes of ownership, the Daily Mail in particular is still owned by descendants of Viscount Rothermere, one of the paper's founders in 1896. In all of these cases proprietors are likely to have had substantial effects on content (see Temple, 2008: 34-9 for the case of the Daily Mail). By contrast, the Financial Times was owned by Pearson, a publicly listed media and publishing company from 1957 to 2015 (Butler and Butler, 2000; Seymour-Ure, 2000). The Economist has been owned since its' founding by the Economist Newspaper Limited, with $50 \%$ of its' shares owned by Financial News Ltd since 1928. 
Web ApPEndix 2: DescriptIVE STATISTICS FOR DEPENDENT, INDEPENDENT, AND CONTROL VARIABLES

\begin{tabular}{lccccc}
\hline \hline Variable & Mean & Std. Dev. & Min & Max & $\mathrm{N}$ \\
\hline Logged negative rhetoric & 4.67 & .386 & 3.57 & 5.43 & 105 \\
Logged unemployment rate & 1.11 & 1.07 & -2.23 & 2.73 & 105 \\
Logged number of articles & 12.5 & .390 & 11.7 & 13.3 & 105 \\
Logged placebo words & 8.56 & .419 & 7.72 & 9.46 & 105 \\
Defence spending as \% of GDP & 8.98 & 12.0 & 2.43 & 52.0 & 105 \\
Public debt & 93.1 & 61.3 & 25.2 & 237.9 & 105 \\
Tax revenue as \% of GDP & 29.3 & 10.4 & 10.0 & 43.5 & 101 \\
Government non-defence spending as \% of GDP & 26.1 & 9.70 & 9.51 & 42.8 & 105 \\
Political party in government & & & & & \\
Conservative & .485 & .502 & 0 & 1 & 105 \\
Labour & .219 & .416 & 0 & 1 & 105 \\
Coalition & .200 & .402 & 0 & 1 & 105 \\
Liberal & .095 & .295 & 0 & 1 & 105 \\
\hline \hline
\end{tabular}

Notes: Logged negative rhetoric and logged numbers of articles use data from Gale Newsvault (authors' calculations). Public debt, tax revenue as a proportion of GDP, government spending as \% proportion of GDP from (Thomas and Dimsdale, 2016). Means of categorical variables can be interpreted as proportion of total cases falling into specific category. 


\section{Web AppendiX 3: AdDRESSING AUTOCORRELATION}

Table 3a compares an OLS regression model to three models which adjust for autocorrelation in slightly different ways. Model 1 is estimated using OLS. The residuals from this model are negatively autocorrelated with two lags. Model 2 is a Prais-Winsten regression model, which assumes that the autocorrelation follows an AR(1) process. Model 3 is an OLS model with Newey-West standard errors adjusted for serial correlation up to a second lag. Model 4 directly models the autocorrelation process by including 2 lags of the dependent variable, logged change in unemployment, and logged change in the number of articles as predictors. This model was selected by examining a number of autoregressive models with different lag lengths, finding that an $\mathrm{AR}(2)$ model minimises the Bayesian Information Criterion (a commonly used tool for selecting lag length- see table $3 \mathrm{~b}$ below). This model has residuals that exhibit no significant autocorrelation.

Comparing all four models it can be seen that the standard error of the estimate of logged change in unemployment on logged change in negative rhetoric is very similar across all four models (from 0.019 in the Newey model to 0.023 in the OLS model), and statistically significant. Thus, our central result appears to be robust to a variety of different strategies for adjusting for autocorrelation. The majority of models presented in the main article adjust for autocorrelation using Newey-West standard errors adjusted for autocorrelation up to a lag of two and heteroscedasticity.

Table 3a: Robustness of association between unemployment and negative rhetoric to adjustment for autocorrelation.

\begin{tabular}{lcccc}
\hline \hline & \multicolumn{5}{c}{ Annual change in the average frequency } \\
& $(1)$ & $(2)$ & $(3)$ & $(4)$ \\
& OLS & Prais & Newey & AR(2) \\
Method & $0.058^{*}$ & $0.063^{* *}$ & $0.058^{* *}$ & $0.065^{* *}$ \\
Increase in the unemployment & $(0.023)$ & $(0.021)$ & $(0.019)$ & $(0.021)$ \\
rate (log) & $0.77^{* * *}$ & $0.83^{* * *}$ & $0.77^{* * *}$ & $0.85^{* * *}$ \\
Increase in the total number of & $(0.11)$ & $(0.10)$ & $(0.13)$ & $(0.091)$ \\
published articles (log) & -0.0069 & -0.0072 & -0.0069 & -0.0074 \\
Constant & $(0.011)$ & $(0.0086)$ & $(0.0085)$ & $(0.0074)$ \\
& & & & $-0.33^{* *}$ \\
AR(1) & & & & $(0.097)$ \\
& & & & $-0.23^{*}$ \\
AR(2) & 105 & 105 & 105 & 105 \\
& & & & \\
\hline Observations
\end{tabular}

Notes: Standard errors in parentheses. ${ }^{*} \mathrm{p}<0.05,{ }^{* *} \mathrm{p}<0.01,{ }^{* * *} \mathrm{p}<0.001$. Prais-Winsten regression models assume that the autocorrelation follows an AR(1) process. Newey model contains standard errors that are adjusted for serial correlation up to the second lag and heteroscedasticity. Autoregressive model contains two lags of the dependent variable, and two lags of both independent variables. 
Table 3b: Bayesian Information Criterion from ARIMA models with various lag lengths

\begin{tabular}{cc}
\hline \hline Lag length & Bayesian Information Criterion \\
\hline 0 & -145.8 \\
1 & -148.4 \\
2 & -149.1 \\
3 & -146.9 \\
4 & -142.3 \\
5 & -139.8 \\
6 & -135.7 \\
\hline \hline
\end{tabular}




\section{WeB APPENDIX 4: ROBUSTNESS OF RELATIONSHIP BETWEEN UNEMPLOY- MENT AND NEGATIVE RHETORIC TO ALTERNATE CONTROLS FOR WAR AND DEFENCE SPENDING AND GENERAL ELECTIONS}

Table 4a displays regression models with alternative controls for wartime. Model 1 uses defence spending as a percentage of GDP as a proxy for war-time. Model 2 codes the first and second world wars separately and model 3 includes additional wars - the Boer War, Falklands War, and the first Gulf War. Our estimate of the association between changes in logged unemployment and logged negative rhetoric is very similar in magnitude to model 1 in table 2 in the main text, and remains statistically significant.

Table 4a: regression models with controls for defence spending and alternative specifications of war-time.

\begin{tabular}{|c|c|c|c|}
\hline & \multicolumn{3}{|c|}{$\begin{array}{l}\text { Annual change in the average frequency } \\
\text { of negative words }\end{array}$} \\
\hline & (1) & (2) & (3) \\
\hline \multirow[t]{2}{*}{ Increase in the unemployment rate $(\log )$} & $0.042^{*}$ & $0.054^{* *}$ & $0.056^{* *}$ \\
\hline & $(0.017)$ & $(0.019)$ & $(0.019)$ \\
\hline Increase in defence spending as a & $-0.0046^{* * *}$ & & \\
\hline$\%$ of GDP & $(0.0010)$ & & \\
\hline Increase in the total number of & $0.70^{* * *}$ & $0.72^{* * *}$ & $0.74^{* * *}$ \\
\hline published articles (log) & $(0.13)$ & $(0.14)$ & $(0.13)$ \\
\hline \multicolumn{4}{|l|}{ No war (ref) } \\
\hline \multirow[t]{2}{*}{ WW1 } & & -0.024 & \\
\hline & & $(0.039)$ & \\
\hline \multirow[t]{2}{*}{ WW2 } & & -0.036 & \\
\hline & & $(0.039)$ & \\
\hline \multicolumn{4}{|l|}{ No war (ref) } \\
\hline \multirow[t]{2}{*}{ Any war } & & & -0.022 \\
\hline & & & $(0.029)$ \\
\hline \multirow[t]{2}{*}{ Constant } & -0.0057 & -0.0027 & -0.0017 \\
\hline & $(0.0085)$ & $(0.0095)$ & $(0.0100)$ \\
\hline Observations & 105 & 105 & 105 \\
\hline
\end{tabular}

Notes: Standard errors in parentheses. ${ }^{*} \mathrm{p}<0.05,{ }^{* *} \mathrm{p}<0.01,{ }^{* * *} \mathrm{p}<0.001$. All models estimated using Newey-West standard errors which are adjusted for serial correlation up to the second lag and heteroscedasticity. Data on defence spending as a percentage of GDP from Mitchell (2007).

Table $4 \mathrm{~b}$ displays models with additional controls for the years in which general elections were held. Model 1 is a base model and includes just unemployment rates and the number of articles published in a given year. Model 2 adds elections as a dummy and then model 3 adds elections as a change variable, capturing whether moving into an election year is correlated with stigmatizing rhetoric. In both cases, there is no clear association. 
Table 4b: Regression models with controls for election years.

\begin{tabular}{lccc}
\hline \hline & \multicolumn{3}{c}{ Annual change in the average frequency } \\
& $(1)$ & $(2)$ & $(3)$ \\
& $0.058^{* *}$ & $0.058^{* *}$ & $0.058^{* *}$ \\
\hline Increase in the unemployment rate $(\log )$ & $(0.019)$ & $(0.020)$ & $(0.020)$ \\
& $0.77^{* * *}$ & $0.75^{* * *}$ & $0.76^{* * *}$ \\
Increase in the total number of & $(0.13)$ & $(0.13)$ & $(0.13)$ \\
published articles $(\log )$ & & -0.033 & \\
Election year $(=1)$ & & $(0.026)$ & \\
& & & -0.0033 \\
Change in elections & & & $(0.016)$ \\
& & & -0.0069 \\
Constant & -0.0069 & 0.00077 & $(0.0086)$ \\
& $(0.0085)$ & $(0.011)$ & 105 \\
\hline Observations & 105 & 105 & \\
\hline \hline
\end{tabular}

Notes: Standard errors in parentheses. ${ }^{*} \mathrm{p}<0.05,{ }^{* *} \mathrm{p}<0.01,{ }^{* * *} \mathrm{p}<0.001$. All models estimated using Newey-West standard errors which are adjusted for serial correlation up to the second lag and heteroscedasticity. 


\section{WeB APPENDIX 5: HOW THE RELATIONSHIP BETWEEN CHANGES IN UNEM- PLOYMENT AND CHANGES IN STIGMATISING RHETORIC DEPEND ON START- ING LEVELS OF UNEMPLOYMENT}

Table 5a below shows the regression model on which figure 2 in the main text was based. It Builds on model 1 in table 2 by introducing an interaction between changes in the unemployment rate and starting levels of unemployment.

Table 5a: How the relationship between changes in unemployment and changes in stigmatising rhetoric depend on starting levels of unemployment

\begin{tabular}{lc}
\hline \hline & $\begin{array}{c}\text { Annual change in the average } \\
\text { frequency of negative words } \\
(1)\end{array}$ \\
\hline Increase in the unemployment rate $(\log )$ & $0.083^{* *}$ \\
& $(0.025)$ \\
Unemployment rate & -0.0012 \\
& $(0.0024)$ \\
Increase in the unemployment rate $(\log ) \times$ & $-0.0069^{*}$ \\
Unemployment rate & $(0.0034)$ \\
Increase in the number of published articles $(\log )$ & $0.75^{* * *}$ \\
& $(0.13)$ \\
Constant & 0.0012 \\
& $(0.013)$ \\
\hline Observations & 105 \\
\hline \hline
\end{tabular}

Notes: Standard errors in parentheses. ${ }^{*} \mathrm{p}<0.05,{ }^{* *} \mathrm{p}<0.01,{ }^{* * *} \mathrm{p}<0.001$. All models estimated using Newey-West standard errors which are adjusted for heteroscedasticity and serial correlation up to the second lag. Descriptive statistics for all control variables are given in Web Appendix 2. 


\section{WeB APPENDIX 6: TYPICAL AND DEVIANT CASE SELECTION}

In this web appendix we provide more details regarding the different components of the typical and deviant case analysis. This analysis is based on the procedure developed by Seawright (2016).

\section{Step 1: Selecting typical and deviant cases}

We selected 1901 and 1991 as our typical cases - these are years where there was a low residual (the model fit well) and a rise in unemployment (see table 6a). In 1901 we selected the words Pauper* (11\% rise) and Loafer* (14\% rise) while in 1991 we selected the words underclass (a decline in this year but from very high levels unique to the $1990 \mathrm{~s})$ and vagrant* (11\% rise). We selected 1934 and 1980 as our deviant cases - these are years where there was a high residual (the model fit poorly). In particular, we look at years where negative rhetoric appears to have risen. In 1934 we selected Tramp* (33\% rise) and unemployable (43\% rise) while in 1980 we selected beggar* (49\% rise) and workshy (a small decline in this year but to its 4 th highest value concentrated in the 1980s).

Table 6a: Identifying typical and deviant cases

\begin{tabular}{lccc}
\hline \hline Year & $\begin{array}{c}\text { Percentage-point change in } \\
\text { unemployment rate }\end{array}$ & Residual & Words selected \\
\hline Typical & & & \\
\hline 1901 & 0.76 & -0.05 & Pauper* and Loafer* \\
1991 & 2.1 & -0.03 & Vagrant $^{*}$ and Underclass \\
\hline Deviant & & & \\
\hline 1934 & -2.21 & 0.25 & Unemployable and Tramp \\
1980 & 1 & 0.26 & Beggar* and Workshy \\
\hline \hline
\end{tabular}

Step 2: Coding the articles

In each year, we read the first 100 randomly selected or, if there were fewer than 100 articles, we read every article. We used a 4 category coding scheme which had been developed by both authors. This tried to identify - as the results indicate - irrelevant uses of the key words. When the words were used in the context of poverty, the articles were coded according to whether the article deployed this term in the context of the stigmatising assumptions that are often associated with these pejorative descriptions of the poor.

\section{Step 3: Checking intercoder reliability}

After the main coding was completed, another author also coded 2 key words from two different years ('underclass' in 1991 and 'tramp' in 1934). The degree of intercoder agreement was relatively high for 'underclass' (Kappa statistic $=0.567, \mathrm{z}$-score $=5.81$ ) and very high for 'tramp' (Kappa statistic $=0.800$, z-score $=8.20$ ). While the coding was not perfectly matched, there is a high degree of agreement between the two coders. 
Table 6b: Examples of usage coded in each category

\begin{tabular}{|c|c|c|c|}
\hline Stigmatising/Negative & Sympathetic/Positive & Neutral & Irrelevant \\
\hline $\begin{array}{l}\text { 'A family of paupers, } \\
\text { extending to three } \\
\text { generations, has cost } \\
\text { the ratepayers of the } \\
\text { Paddington Union a } \\
\text { sum of } £ 3,000 ’ \\
\text { (Hereditary Pauperism, } \\
\text { Daily Mail, November } \\
\text { 21, 1901) }\end{array}$ & $\begin{array}{l}\text { 'A pathetic letter, } \\
\text { which throws a flood } \\
\text { of light on the terrible } \\
\text { monotony of life in a } \\
\text { workhouse' (A day in a } \\
\text { Pauper's Life, Daily } \\
\text { Mail, October 29, } \\
\text { 1901) }\end{array}$ & $\begin{array}{l}\text { 'Mr How is highly } \\
\text { educated, and spends } \\
\text { most of his time } \\
\text { travelling about the } \\
\text { country, mixing with } \\
\text { tramps and other } \\
\text { outcasts' (A Pauper } \\
\text { Millionaire, Daily Mail, } \\
\text { October 9, 1901) }\end{array}$ & $\begin{array}{l}\text { 'The man found dead } \\
\text { under a hedge... and } \\
\text { since buried in a } \\
\text { pauper's grave, was } \\
\text { John Howard Bullheid' } \\
\text { (Solicitor's Strange } \\
\text { Death, Daily Telegraph } \\
\text { October 9, 1901) }\end{array}$ \\
\hline $\begin{array}{l}\text { 'Verminous tramps... } \\
\text { and loafers' (Tramp } \\
\text { Plague in London, } \\
\text { November 8, 1901, } \\
\text { Daily Telegraph) }\end{array}$ & $\begin{array}{l}\text { 'People sleeping rough } \\
\text { in indescribable } \\
\text { squalor' (More aid to } \\
\text { vagrants as MPs voice } \\
\text { worries, The Times, } \\
\text { February 9, 1991) }\end{array}$ & $\begin{array}{l}\text { 'An admiring crowd of } \\
\text { loafers' (A derby } \\
\text { disappointment, Daily } \\
\text { Telegraph, June 6, } \\
\text { 1901) }\end{array}$ & $\begin{array}{c}\text { 'Author of "The } \\
\text { Chronic Loafer"' (A } \\
\text { drone and a dreamer, } \\
\text { The Times, December } \\
\text { 19, 1901) }\end{array}$ \\
\hline $\begin{array}{l}\text { 'Gangs of drunken } \\
\text { beggars... aggressive } \\
\text { vagrants' (Menace of } \\
\text { the beggars who strike } \\
\text { fear in heart of } \\
\text { London, Daily Mail, } \\
\text { June 17, 1991) }\end{array}$ & $\begin{array}{l}\text { 'An underclass is } \\
\text { formed by a physical } \\
\text { concentration of social } \\
\text { problems' (The } \\
\text { Underclass is no } \\
\text { Illusion, Financial } \\
\text { Times, April 22, 1991) }\end{array}$ & $\begin{array}{l}\text { 'His chosen descent } \\
\text { into the underworld of } \\
\text { the workless and } \\
\text { vagrant' (Making it } \\
\text { seem virtuous to eat } \\
\text { bacon, Daily Telegraph, } \\
\text { October 19,1991) }\end{array}$ & $\begin{array}{c}\text { 'Jimmy finds a vagrant } \\
\text { who has moved in' (TV } \\
\text { Listing for Casualty, } \\
\text { November 8, 1991) }\end{array}$ \\
\hline $\begin{array}{c}\text { 'A deeper revolt by an } \\
\text { underclass of teenagers } \\
\text { seemingly no longer } \\
\text { able to communicate } \\
\text { with society' (Cooling } \\
\text { the Hotheads, Sunday } \\
\text { Telegraphy, September } \\
8,1991 \text { ) }\end{array}$ & $\begin{array}{l}\text { 'Described the men for } \\
\text { whom the appeal was } \\
\text { made as unemployable } \\
\text { on the general labour } \\
\text { market' (Helping hand } \\
\text { for ex-servicemen, } \\
\text { Daily Telegraph, } \\
\text { October } 13,1934 \text { ) }\end{array}$ & $\begin{array}{c}\text { 'There is no common } \\
\text { culture of the } \\
\text { underclass' (The stuff } \\
\text { of a thousand suburban } \\
\text { novels, Daily } \\
\text { Telegraphy, February } \\
15,1991 \text { ) }\end{array}$ & $\begin{array}{l}\text { 'Japan Airlines is } \\
\text { scrapping an in-flight } \\
\text { magazine which } \\
\text { referred to... a social } \\
\text { underclass' (Touchy } \\
\text { Subject, Daily } \\
\text { Telegraph, November } \\
\text { 8, 1991) }\end{array}$ \\
\hline $\begin{array}{l}\text { “Tramps”... are an } \\
\text { enemy of society' } \\
\text { (Crime in Scotland, } \\
\text { The Times, May 2, } \\
\text { 1934) }\end{array}$ & $\begin{array}{l}\text { 'Evangelism is like one } \\
\text { beggar telling another } \\
\text { where to find bread' } \\
\text { (Theologians united on } \\
\text { Christian message, The } \\
\text { Times, July 28, 1980) }\end{array}$ & $\begin{array}{c}\text { 'We have never } \\
\text { suggested that all the } \\
2 \mathrm{~m} \text { jobless were } \\
\text { workshy' (Plight of the } \\
\text { unemployed, Financial } \\
\text { Times, September 12, } \\
1980 \text { ) }\end{array}$ & $\begin{array}{c}\text { 'One of the troubles of } \\
\text { the tramp steamer' } \\
\text { (Liners' Bid for } \\
\text { Freights 'Filching from } \\
\text { Tramps', Daily } \\
\text { Telegraph, December } \\
\text { 1, 1934) }\end{array}$ \\
\hline
\end{tabular}




\begin{tabular}{|c|c|c|c|}
\hline $\begin{array}{c}\text { 'The recession has } \\
\text { already been driving... } \\
\text { endemic crime, } \\
\text { prostitution, and } \\
\text { beggary' (The } \\
\text { tinderbox, The } \\
\text { Economist, May 17, } \\
\text { 1980) }\end{array}$ & $\begin{array}{l}\text { 'It reflected a collection } \\
\text { of Tory myths about } \\
\text { social security, the } \\
\text { workshy, and the } \\
\text { unemployed' } \\
\text { (Unemployed 'Being } \\
\text { Made Scapegoats for } \\
\text { Economic Ills', Daily } \\
\text { Telegraph, April 1, } \\
\text { 1980) }\end{array}$ & $\begin{array}{l}\text { 'When beggars die, } \\
\text { there are no comets } \\
\text { seen' (Let them die } \\
\text { with dignity, The } \\
\text { Times, April 29, 1980) }\end{array}$ & $\begin{array}{c}\text { 'Beggar's Bridge' } \\
\text { (Racing, Daily Mail, } \\
\text { July 4, 1980) }\end{array}$ \\
\hline
\end{tabular}

We have also reproduced 3 articles used in this analysis below.

Table 6c: Number of articles coded in each category for each word

\begin{tabular}{lcccccc}
\hline \hline \multicolumn{7}{l}{ Typical case (High unemployment - high negative rhetoric) } \\
\hline Year & Word & Negative & Sympathetic & Neutral & Irrelevant & Total \\
\hline 1901 & Pauper* & 74 & 24 & 29 & 3 & 130 \\
& $\%$ & 56.9 & 18.5 & 22.3 & 2.3 & 100 \\
1901 & Loafer* & 45 & 0 & 5 & 34 & 84 \\
& $\%$ & 53.6 & 0.0 & 6.0 & 40.5 & 100 \\
1991 & Vagrant* & 45 & 5 & 7 & 42 & 99 \\
& $\%$ & 45.5 & 5.1 & 7.1 & 42.4 & 100 \\
1991 & Underclass & 52 & 18 & 15 & 14 & 99 \\
& $\%$ & 52.5 & 18.2 & 15.2 & 14.1 & 100 \\
\hline Deviant case (high negative rhetoric - low change in unemployment) & \\
\hline 1934 & Unemployable & 10 & 5 & 6 & 9 & 30 \\
& $\%$ & 33.3 & 16.7 & 20.0 & 30.0 & 100 \\
1934 & Tramp & 17 & 1 & 14 & 67 & 99 \\
& $\%$ & 17.2 & 1.0 & 14.1 & 67.7 & 100 \\
1980 & Beggar* & 17 & 1 & 7 & 74 & 99 \\
& $\%$ & 17.2 & 1.0 & 7.1 & 74.7 & 100 \\
1980 & Workshy & 5 & 3 & 8 & 14 & 30 \\
& $\%$ & 16.7 & 10.0 & 26.7 & 46.7 & 100 \\
\hline \hline
\end{tabular}

Notes: Workshy spikes because it was the name of a horse. Unemployable is used to refer to blindness quite a bit and there was some concern about charity for these groups. Tramp is highly irrelevant because there was a shipping crisis and one of the types of ships involved was called a 'tramp'. Beggar* is highly irrelevant because there was theatrical production titled 'The Beggar's Opera' and Lester Piggott rode a horse called Beggars Bush. These both received a lot of coverage. 


\section{'King of the Beggars' knocked off throne}

\section{STAR'S WIFE DEFIES DOCTORS}

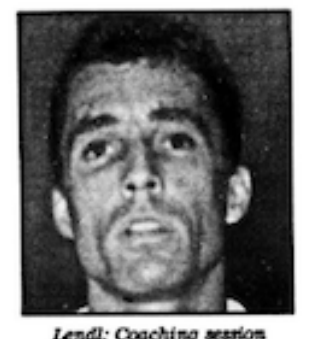

Why I had to be with Ivan, by pregnant Mrs Lendl

IVAN LENDL's pregnant wife has defied doctors to join him 1or wimb she said yesterday.

Bamantha Lendl, expecting
twins in August, finsisted that she could not bear to be svay' trom the tenn
month. Doetors had enoouraged her to
remanin at home in Connectieut as her husband went in seareh of eluded him

They were angry at firnt they Gid not want me to house overlooking wimbledon Common.

Whatever the rtak might be and 1 don't think im taking any risi, $T$ m happlez with fvan par That makes good medical sense suaded the doetors

The couple are peying 118,000 for their house and are among

\section{By DAVD WIயAMS, Chief Reporter}

A MAN nicknamed ' $\mathrm{K}$ ing of the Beggars' rammed a broken bottle into the face of a City broker who refused him money, the Old Bailey heard yesterday.

Drunken Edmund Williams punched and kicked rugby player Michael Heraghty, 27, as he fell to the ground, blood pouring from his face, in the heart of the West End.

The sttack scarred him for life as the glass ripped rowly missing an eye and into his mouth.

Last night, after Willams also 27 , was fliled for four ing menace of vilovence on the capltal's streets from st new breed of beckars who

One man sas stabbed to Dounded near Berkeley Bquare last month.

Wiltams was a clasesc exarsple of the new breed, runining What one officer in the case atlon:

He did tittie begring himself

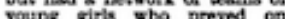
tourists and workers around of their coldections which could of their collections which coul
avenage
cola-day each.

\section{Racket}

Potice believe he was also a as taxing. robbing the genut cometimn Although he a family houme in camden Town, North London.

Buch is the money to be considerable in-fighting ove: the pontros tho mos lucrscriminats are belng crawa in. both violence and begzing both violence and begring.

Pollee have set up an under Taurus, to ideatity those 'Dulling the stringe' behind the ruckets. If who arrested Williams.

Pussing sentence Froterday Wiams who sdmitied grievcus bodily harm, that begging thas in un

\section{Menace of the violent vagrants}

But he marned that people
who refused to hand git? money should be entilied to teel sate'.

Mr. Heraghty, who lives in Willams and two other men is be lett a Covent Carós ro caunnt in December.

They were persistent and abusive, ho and hast night although I teit sorry for them I would not give them anything: He sald the three rept shous tng "Olve us some money, you

As he tried to nilk swy. they started to yotie

But the former funior black wo of the men backd ctr. I wregtied Williams to the do not want to fight me. 1 fart want to 50 home?

I began to walk assy but 1 suppoes he thought he had polnt to prove, he had loet fice In tront of his friends. 1 hears glass breaking and os 1 spun tace. There ons a lot of bloot and wilisms man oft.

Iater that night he went back with stacker.
hls stald

Comment - Page SLX belt at fudo fought back an 


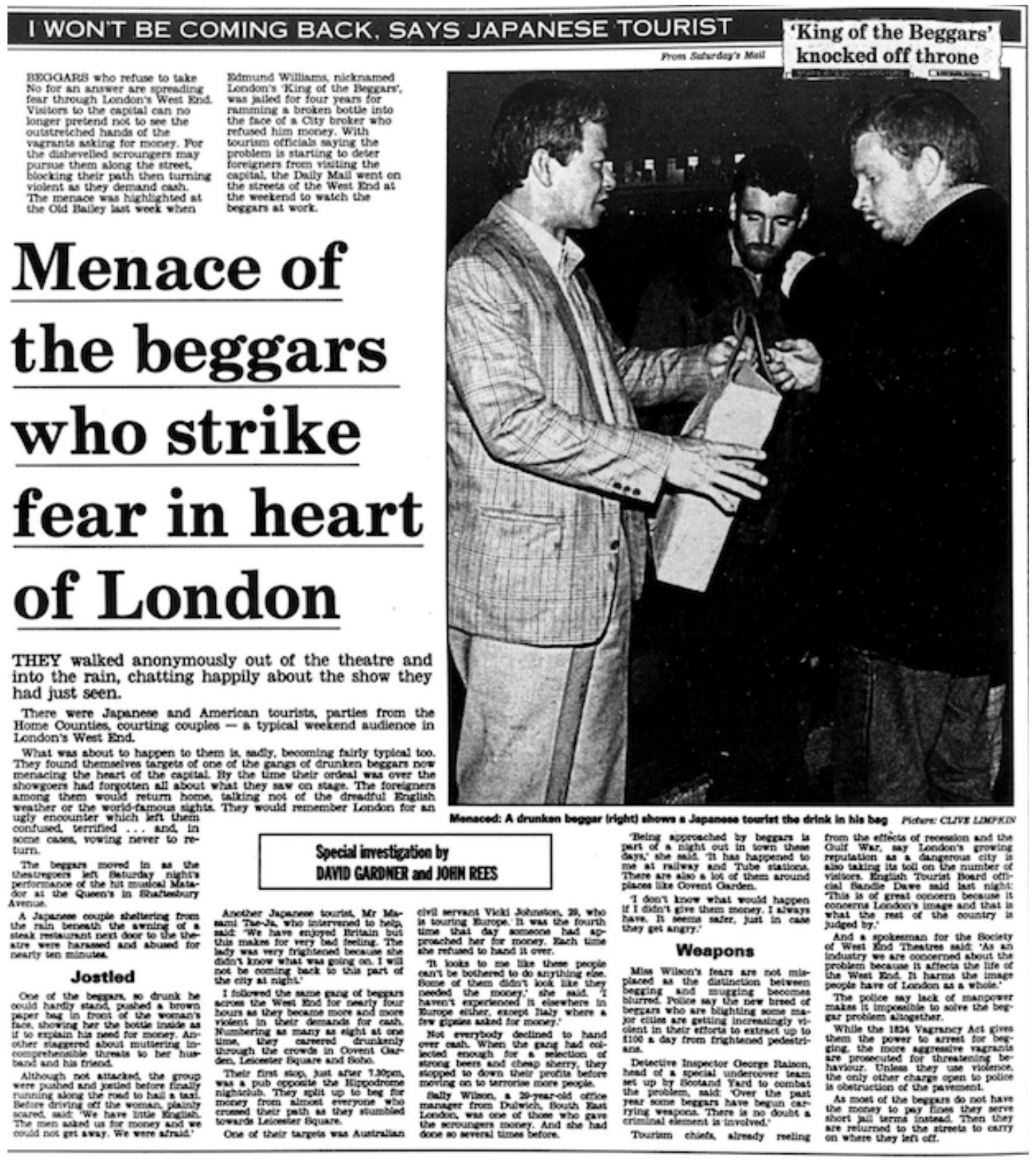




\section{TRAMP PLAGUE IN LONDON.}

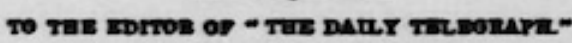

Sn- Small-pox is rampant in Iondon; searlet fover and diphtheris arv increasing in evety part of the metropolis in an alarming degree. Medical offeers of bealth, sanitary inspectors, and other dirtriot officials are bravely doing their best to meet and defeat one of the most dangerout outbreals of divease that Iondon has lnown for many years past; but there is one department which a far as anyone's general observation can make out seems to do nothing whatover to ansist the municipal suthorities at this juncture.

The department I allude to is that which controls the Metropolitan Police. At this moment there are more professional vagrante and trampo " smoveching" about the streets of London thin norel, and tbey ane of the filthieat dewcription. Bvery report respecting the apread of ownell-pox and scarlet forer bot to mention diphtheri showe that infection is being carried about the streets by the verminous trinipe, who are now a positive plagro in Iondon. As soon as they collect any money they adjourn to a publio-house, and there, by their clowe contact with others, insure the dissemination of disease. These vagrants nemble in knote at the comers of the streeta and in the parks, jostle up soginet penory and undoubtedly are ac00untable for much of the increase of the illineses now 10 prevalent.

Ono would imagine that, under the existing circumstances, the Metropolitan Polioe woold be instracted to " rma in" people who are obvioenly tramps and lonfors-persons not having any ririble means of subsistenos- and hare them die infected and raceinated. I exppose, however, the latter prooess is impoesible under tbe existing idiotio legeslation, bet, at any rates steps should bo takea by the potioe largely to clear the I condon streots and the parlos-especially those parte where children are socustomed to play- of what is now a dangeroes anisance. As far ap ono can judge, the retropolitan Polioe are doing abeoFutaly nothing in this direction. They look on with unmoved complacency when they see some appallingly loathame object rub up agninst his fellow-crsatures, with the risk of communicating to them somo hideons disease.

In paosing, I may add that to a great many who pay for the and police it sometimes seems that nowradays that force exista principally for the regulation of atreet trafio. Of course, it will be anid that the strecte are free to all. \&o they are; but with certain exoeptions. A very drumken wen or anyone gaing $\mathrm{eb}$ out with a drawn frifo would not be allowed to continne his wasderings. Why, therefore, should an invacion of the lowest and wost dingusting human beings, bringing with them diseanes and filth, bo per unttind io poinon the streote of London? W. sbould at least inviat that they should repair to some place where they could bo cleansed. As it is, they are a positive denger to our parka and public pleces, and their shamele appearance among decent people is a disgrace to the management of Londan.

Now, when the efforte of ereryone holding any athority in the motropolis should bo directed towards checking the spread of the grave diseases which are gaining such hold apon erery district, eurely among the myrieds of Acts of Parliament, police and otherwise, one could be found which would meet the exigencies of the present case?I am, Bir, yours obediently,

GRANBY.

Arlington-street, Nov. 7. 